\title{
Dietary Sphingolipids Contribute to Health via Intestinal Maintenance
}

\author{
Shinji Yamashita ${ }^{1}$, Mikio Kinoshita ${ }^{1, *(1)}$ and Teruo Miyazawa ${ }^{2}$ \\ 1 Department of Life and Food Sciences, Obihiro University of Agriculture and Veterinary Medicine, \\ Obihiro 080-8555, Japan; syamashita@obihiro.ac.jp \\ 2 Food and Biotechnology Platform Promoting Project, New Industry Creation Hatchery Center (NICHe), \\ Tohoku University, Sendai 980-8579, Japan; teruo.miyazawa.a7@tohoku.ac.jp \\ * Correspondence: kinosita@obihiro.ac.jp; Tel.: +81-155-49-5545
}

Citation: Yamashita, S.; Kinoshita, M.; Miyazawa, T. Dietary Sphingolipids Contribute to Health via Intestinal Maintenance. Int. J. Mol. Sci. 2021, 22, 7052. https://doi.org/ $10.3390 /$ ijms 22137052

Academic Editor: Paola Giussani

Received: 15 June 2021

Accepted: 26 June 2021

Published: 30 June 2021

Publisher's Note: MDPI stays neutral with regard to jurisdictional claims in published maps and institutional affiliations.

Copyright: (C) 2021 by the authors Licensee MDPI, Basel, Switzerland. This article is an open access article distributed under the terms and conditions of the Creative Commons Attribution (CC BY) license (https:// creativecommons.org/licenses/by/ $4.0 /)$.

\begin{abstract}
As sphingolipids are constituents of the cell and vacuole membranes of eukaryotic cells, they are a critical component acquired from our daily diets. In the present review, we highlight the knowledge regarding how dietary sphingolipids affect our health, particularly our intestinal health. Animal- and plant-derived foods contain, respectively, sphingomyelin (SM) and glucosylceramide (GlcCer) as their representative sphingolipids, and the sphingoid base as a specific structure of sphingolipids also differs depending upon the source and class. For example, sphingosine is predominant among animal sphingolipids, and tri-hydroxy bases are present in free ceramide (Cer) from plants and fungi. Dietary sphingolipids exhibit low absorption ratios; however, they possess various functions. GlcCer facilitates improvements in intestinal impairments, lipid metabolisms, and skin disorders, and SM can exert both similar and different effects compared to those elicited by GlcCer. We discuss the digestion, absorption, metabolism, and function of sphingolipids while focused on the structure. Additionally, we also review old and new classes in the context of current advancements in analytical instruments.
\end{abstract}

Keywords: ceramide; glucosylceramide; inflammation; intestine; sphingomyelin; sphingosine

\section{Introduction}

The intestine digests food materials and absorbs nutrients and water and is also deeply implicated in human health maintenance via the immune and nervous systems [1]. However, intestinal impairments, such as colon cancer and inflammatory bowel disease (IBD), are becoming increasingly problematic pathologies that affect both sexes worldwide. Despite advances in the diagnosis and treatment of these diseases, their incidence rates have steadily increased in East Asian countries, including Japan, and their incidence rates in Western countries also remain high [2,3]. Epidemiological studies indicate that intestinal impairments are strongly associated with diet [4], and dietary compounds directly interact with the colonic epithelium cells and may affect growth, differentiation, and cell death within the tissue [5]. Endogenous sphingolipids are known to play key roles in inflammation-related diseases, including intestinal impairment [6,7]. Although dietary sphingolipids are also believed to be implicated in these diseases, food-derived sphingolipids differ from endogenous sphingolipids in regard to their different structures among plants, fungi, and invertebrates and their differing routes into the body, which can include digestion and absorption [8]. In this review, we introduce sphingolipids as foods or supplements that can facilitate various functions, such as influencing intestinal health, and we focus primarily on sphingolipid structure in this context.

\section{Diversity of Sphingolipid Classes and Base Composition in Foods}

Sphingolipids are primarily located within the cell and vacuole membranes of most eukaryotes and some prokaryotes, and, based on this, we consume sphingolipids daily in 
our diets. Sphingolipids present in most foods primarily exist as complex sphingolipids that are composed of a sphingoid base (SB) with an amide-linked fatty acid (i.e., ceramide, Cer) and a polar head group, rather than a free Cer [8]. Throughout nature, there are diverse compositions of sphingolipid classes and sphingoid bases (Figure 1).

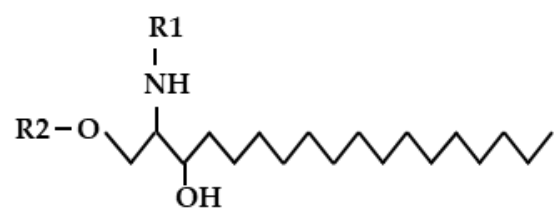

Free sphingoid base (SB) $\mathrm{R} 1, \mathrm{R} 2=\mathrm{H}$

Free ceramide (Cer) $\mathrm{R} 1=$ Fatty acid, $\mathrm{R} 2=\mathrm{H}$

Sphingomyelin (SM) R1 = Fatty acid $\mathrm{R} 2=$ Phosphocholine Galactosylceramide (GalCer) R1 = Fatty acid, R2 = Galactose
Glucosylceramide (GlcCer) R1 = Fatty acid, R2 = Glucose

Cer 2-aminoethylphosphonate (CAEP)

R1 $=$ Fatty acid,

R2 = 2-Aminoethylphosphonate

Ganglioside

R1 = Fatty acid,

R2 = Sialic acids + Saccharides

Glycosylinositol phosphoceramide (GIPC)

R1 = Fatty acid,

R2 = Phosphoinositol + Saccharides

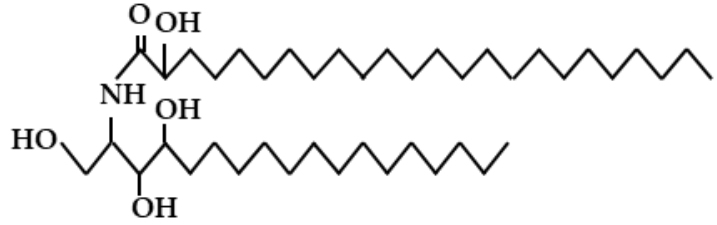

Cer (C24h:0-t18:0)

Animals Fungi

$\mathrm{d} 18: 1^{\text {4t }} \quad \mathrm{d} 18: 0 \quad \mathrm{t} 18: 0 \quad \mathrm{t} 20: 0 \quad \mathrm{t} 18: 0 \quad \mathrm{~d} 18: 0$

Plants Marine invertebrates

$\mathrm{t} 18: 0 \quad \mathrm{t} 18: 1^{\text {st }} \mathrm{t} 18: 1^{\text {sc }}$ Unique SBs

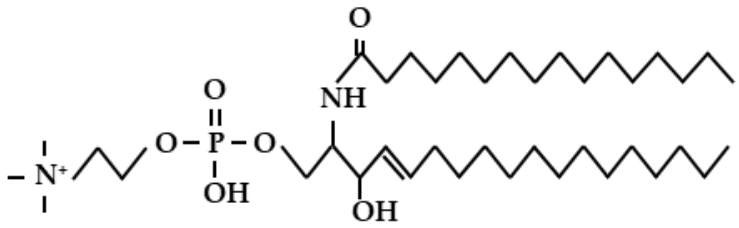

SM (C16:0-d18:1 $\left.{ }^{4 t}\right)$

Animals

d18:1 $1^{\text {tt }}$ d18:0 $\quad \mathrm{t} 18: 0$
Marine invertebrates

Unique SBs

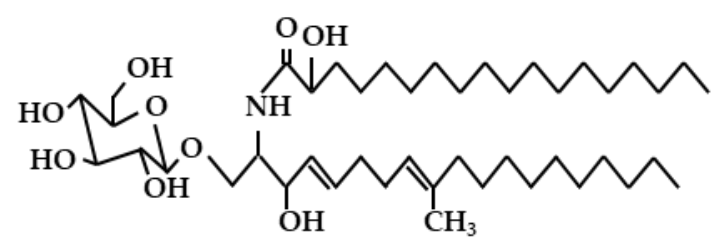

GlcCer (C18h:0-9-Me d18:2 $2^{4 t, 8 t}$ )

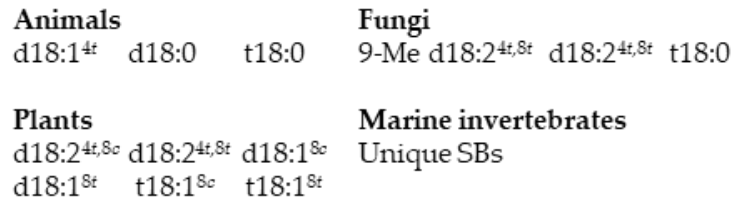

Figure 1. Structures of sphingolipids and diversity of sphingoid bases depend on food sources. Abbreviations: $\mathrm{C}$, carbon number; $c$, cis; $d$, dihydroxy; $h$, $\alpha$-hydroxy; Me, methyl; t, trans; $t$, trihydroxy.

Sphingolipids are typically classified as neutral and acidic sphingolipids. Neutral sphingolipid classes in animal-derived foods such as meats and egg yolk primarily consist of sphingomyelin (SM; a phosphocholine as the polar head group) and also include glucosylceramide (GlcCer; a glucose) and Cer, while the acidic sphingolipid classes are gangliosides that contain more than one sialic acid within the sugar chain [9,10]. Milk and dairy products contain GlcCer and lactosylceramide (LacCer) in addition to SM, and they are rich in gangliosides $[10,11]$. The sphingolipid composition of offal (variety meats, e.g., brain, spinal cord, liver, and intestine) is unique. For example, the brain and spinal cord, both of which are abundant in sphingolipids, contain large amounts of galactocylceramide (GalCer) and sulfatides that are represented by GalCer 3-sulfate. The neutral sphingolipids from fish-derived foods are primarily SM and monoglycosylceramides (e.g., GalCer and GlcCer) [12,13], while foods from invertebrates such as Mollusca contain Cer phosphoethanolamine and Cer 2-aminoethylphosphonate (CAEP) instead of SM [14]. The polar head group of CAEP possesses a C-P bond that consists of a phosphorus atom that is directly bound to a carbon atom. In contrast, neutral sphingolipid classes present in foods derived from plants are primary composed of GlcCer and Cer, and rice and wheat grains contain small amounts of oligo-glycosyl Cer that possess sugar chains that are composed of glucose and mannose [15]. Plant acidic sphingolipids comprise inositol phosphoceramide (IPC) and glycosyl IPC (GIPC), both of which are markedly more abundant than is GlcCer [16]. Foods 
derived from fungi such as mold and mushrooms possess GlcCer, GalCer, and LacCer as neutral classes and IPC and GIPC as acidic classes [17]. Although general eukaryotes can possess higher or lower levels of GlcCer, yeasts (Saccharomyces cerevisiae) used for panary fermentation and sake brewing do not contain GlcCer, while yeasts contain Cer, IPC, and GIPC [18]. Additionally, sphingolipids do not exist in general prokaryotes, but Cer and the specific derivatives, such as Cer glucuronide, are present in certain prokaryotes, including acetic acid bacteria (Acetobacter) [19-21]. Fermented foods such as sake lees, a by-product of sake (rice wine) brewing, contain markedly high levels of free Cer and free SBs [22,23].

In regard to animal sphingoid bases, trans-4-sphingenine (sphingosine, $\mathrm{d} 18: 1^{4 t}$ ) is the most prevalent, and sphinganine (d18:0) and 4-hydroxysphinganine (phytosphingosine, t18:0) also occur frequently in small amounts (Table 1). However, the small intestine, kidney, and skin, which exhibit C4-hydroxylase activity, are abundant in t18:0 [24]. Plant sphingolipids exhibit a highly diverse SB composition due to having $\Delta 8$-unsaturation and these compositions can include trans-8-sphingenine $\left(\mathrm{d} 18: 1^{8 t}\right)$, cis-8-sphingenine $\left(\mathrm{d} 18: 1^{8 \mathrm{c}}\right)$, trans4,trans-8-sphingadienine (d18:2 $\left.{ }^{4 t, 8 t}\right)$, trans-4,cis-8-sphingadienine (d18:2 $\left.2^{4 t, 8 c}\right)$, 4-hydroxytrans-8-sphingenine $\left(\mathrm{t} 18: 1^{8 t}\right)$, and 4-hydroxy-cis-8-sphingenine $\left(\mathrm{t} 18: 1^{8 c}\right)$. Plant GlcCer possesses different base compositions depending on the plant species. The predominant bases of GlcCer are d18:2 $2^{4 t, 8 c}$ in rice and maize, d18:2 $2^{4 t, 8 t}$ in soybeans, and d18:1 ${ }^{8 c}$ in wheat and rye (Table 2) [25,26]. Fungal GlcCer primarily comprises the fungi-specific base, 9-methyl-trans-4,trans-8-sphingadienine (9-Me d18:2 $\left.2^{4 t, 8 t}\right)[27,28]$. Cer, IPC, and GIPC primarily comprise the trihydroxy bases t18:0 and t18:18 in plants and of $t 18: 0$ and 4hydroxyicosasphinganine (t20:0) in fungi [17]. Sphingolipids derived from marine invertebrates contain unique sphingoid bases. For example, CAEP in the jumbo flying squid (Dosidicus gigas) primarily comprises 9-methyl-trans-4,trans-8, trans-10-sphingatrienine (9Me d18: $3^{4 t, 8 t, 10 t}$ ) and hexadeca-trans-4-sphingenine (d16:1 $\left.{ }^{4 t}\right)$, and CAEP in the giant scallop (Mizuhopecten yessoensis) primarily comprises 9-Me d18:34t,8t,10t and 4,trans-8, trans-10sphingatrienine $\left(\mathrm{d} 18: 3^{4 t, 8 t, 10 t}\right)$ [29-33].

Table 1. Fatty chain composition (mol\%) of animal-derived sphingomyelins (SM).

\begin{tabular}{|c|c|c|c|c|}
\hline \multirow[b]{2}{*}{ Fatty Chain } & \multicolumn{4}{|c|}{ SM } \\
\hline & $\begin{array}{c}\text { Bovine Milk } \\
\text { [34] }\end{array}$ & $\begin{array}{c}\text { Bovine Brain } \\
{[34]}\end{array}$ & Egg Yolk [34] & $\begin{array}{c}\text { Chicken Skin } \\
{[35]}\end{array}$ \\
\hline Acyl group & \multicolumn{4}{|c|}{ nonhydroxy } \\
\hline C16:0 & 14 & 3 & 66 & 44 \\
\hline C18:0 & 3 & 42 & 10 & 20 \\
\hline C20:0 & 1 & 6 & 4 & 4 \\
\hline C22:0 & 22 & 7 & 6 & 7 \\
\hline C23:0 & 32 & 3 & 2 & 2 \\
\hline C24:0 & 19 & 6 & 5 & 6 \\
\hline C24:1 & 5 & 27 & 3 & 8 \\
\hline Others & 4 & 6 & 4 & 9 \\
\hline \multicolumn{5}{|l|}{ Sphingoid base } \\
\hline d16:0 & 9 & & & \\
\hline $\mathrm{d} 17: 0$ & 15 & & & \\
\hline $\mathrm{d} 17: 1$ & 8 & & & \\
\hline Me-d17:1 & 11 & & & \\
\hline d18:0 & 10 & 19 & 7 & 2 \\
\hline $\mathrm{d} 18: 1^{4 t}$ & 44 & 82 & 93 & 98 \\
\hline d19:0 & 4 & & & \\
\hline
\end{tabular}


Table 2. Fatty chain composition (mol\%) of plant- and fungi-derived glucosylceramides (GlcCer).

\begin{tabular}{|c|c|c|c|c|c|c|c|c|c|}
\hline \multirow[b]{2}{*}{$\begin{array}{l}\text { Fatty } \\
\text { Chain }\end{array}$} & \multicolumn{9}{|c|}{ GlcCer } \\
\hline & $\begin{array}{l}\text { Rice } \\
{[26]}\end{array}$ & $\begin{array}{c}\text { Wheat } \\
\text { [26] }\end{array}$ & $\begin{array}{l}\text { Rye } \\
{[26]}\end{array}$ & $\begin{array}{c}\text { Maize } \\
{[26]}\end{array}$ & $\begin{array}{c}\text { Soybean } \\
{[26]}\end{array}$ & $\begin{array}{c}\text { Konjac } \\
{[26]}\end{array}$ & $\begin{array}{c}\text { Apple } \\
{[36]}\end{array}$ & $\begin{array}{l}\text { Yeast } \\
{[26]}\end{array}$ & $\begin{array}{c}\text { Mushroom } \\
{[28]}\end{array}$ \\
\hline $\begin{array}{l}\text { Acyl } \\
\text { group }\end{array}$ & \multicolumn{9}{|c|}{$\alpha$-hydroxy } \\
\hline C16h:0 & 1 & 39 & 26 & 6 & 82 & 19 & 64 & 1 & 80 \\
\hline C18h:0 & 6 & 7 & 5 & 16 & $<1$ & 32 & $<1$ & 99 & 12 \\
\hline C20h:0 & 50 & 38 & 36 & 39 & $<1$ & 14 & $<1$ & & \\
\hline C22h:0 & 14 & 4 & 8 & 12 & 7 & 17 & 12 & & $<1$ \\
\hline C23h:0 & & & & & & & 7 & & 2 \\
\hline C24h:0 & 21 & 4 & 7 & 21 & 8 & 6 & 15 & & 3 \\
\hline C24h:1 & & 1 & 8 & & & & & & \\
\hline C26h:0 & 3 & 2 & 2 & 3 & 1 & 1 & & & $<1$ \\
\hline Others & 5 & 5 & 8 & 3 & 2 & 11 & 1 & & 3 \\
\hline $\begin{array}{l}\text { Sphingoid } \\
\text { base }\end{array}$ & & & & & & & & & \\
\hline $\mathrm{d} 18: 0$ & 1 & 5 & 4 & 1 & $<1$ & $<1$ & 1 & & 1 \\
\hline $\mathrm{d} 18: 1^{4 t}$ & 4 & 1 & $<1$ & 3 & $<1$ & 1 & $<1$ & & 1 \\
\hline $\mathrm{d} 18: 1^{8 c}$ & $<1$ & 50 & 50 & $<1$ & 5 & 3 & $<1$ & & \\
\hline $\mathrm{d} 18: 1^{8 t}$ & 1 & 21 & 21 & $<1$ & $<1$ & 1 & $<1$ & & \\
\hline $\mathrm{d} 18: 2^{4 t, 8 c}$ & 45 & 9 & 5 & 54 & 24 & 51 & 34 & & \\
\hline $\mathrm{d} 18: 2^{4 t, 8 t}$ & 13 & 4 & 3 & 17 & 49 & 11 & 11 & 20 & $<1$ \\
\hline $\begin{array}{c}9 \mathrm{Me}- \\
\mathrm{d} 18: 2^{4 t, 8 t}\end{array}$ & & & & & & & & 78 & 97 \\
\hline t18:0 & 7 & 1 & 2 & 2 & $<1$ & 1 & 1 & 2 & 1 \\
\hline $\mathrm{t} 18: 1^{8 c}$ & 26 & 8 & 12 & 21 & 12 & 31 & 36 & & \\
\hline $\mathrm{t} 18: 1^{8 t}$ & 3 & 1 & 2 & 2 & 9 & 1 & 17 & & \\
\hline
\end{tabular}

\section{Intake of Sphingolipids from Daily Diets}

A number of researchers have investigated the sphingolipid content in diets. The daily intake of sphingolipids from the American diet has been reported as 300-400 mg according to calculations of the sphingolipid content (SM and glycosphingolipids, including GlcCer and gangliosides) in food materials [9]. The daily Japanese diet contains 130-300 $\mathrm{mg}$ of sphingolipids (80-220 $\mathrm{mg}$ of SM and CAEP; $50-80 \mathrm{mg}$ of GlcCer) for young individuals and $50-80 \mathrm{mg}$ of sphingolipids (10-60 $\mathrm{mg}$ of SM and CAEP; $30 \mathrm{mg}$ of GlcCer) for elderly individuals [37]. Additionally, GlcCer intake from plants has been reported as $50 \mathrm{mg}$ in the daily Japanese diet [38]. Although GIPC levels in plant materials, including cereals and vegetables, are 2- to 9-fold higher than those of GlcCer [16,23], there is still little information regarding GIPC content in the diet due to the complicated extraction and analysis of these components (GIPC is fractionated into the water layer during liquid-liquid extraction along with the organic layer). Based on this, it is likely that the actual daily intake of sphingolipids is greater than the intake levels described above.

\section{Digestion and Absorption of Various Sphingolipids}

As mentioned above, foods contain various complex sphingolipids possessing different polar head groups and SBs. Complex sphingolipids are digested to generate SBs and then absorbed via the lymph, and absorbed SBs are partially resynthesized into complex sphingolipids, while they are predominantly metabolized into fatty acids [8-10,32,39,40]. In the small intestinal mucosa, SM and CAEP are digested to Cer by alkaline-sphingomyelinase (alk-SMase), and glycosylceramides such as GlcCer, GalCer, and LacCer are digested into Cer by glycosylceramidase. The GIPC digestion mechanism has not yet been clarified; however, Cer-1-phosphate, which is generated from GIPC by the self-digestion of plant phospholipase $\mathrm{D}$, is digested to Cer by intestinal alkaline-phosphatase [41]. Subsequently, Cer is digested to SB by ceramidase. It has been reported that undigested GlcCer and Cer are partially absorbed [42,43]. Even in the large intestine, complex sphingolipids and Cer are digested 
by enteric bacteria. The mechanism underlying the absorption of gangliosides is not well defined. Sialidase (neuraminidase) activity, which hydrolyzes the sialic acid residues in the ganglioside sugar chain, is much lower in the small intestinal mucosa of adult mammals than in young mammals [44]. It has been reported that GD3 (a major molecule in milk and dairy products) is not digested and is instead absorbed as an intact molecule in the human intestinal tract model, and GD3 feeding has been demonstrated to increase the levels of lipid rafts from the brush border and plasma in rats [45]. It has also been reported that GD3 is digested into Cer by endoglycosylceramidase in the large intestine based on the observed absence of intermediates (i.e., GlcCer and LacCer) [46].

Oral administration of sphingolipids results in lower digestion and absorption compared to other lipids. Additionally, the digestive ratio depends upon the sphingolipid classes and the fatty acid composition, and the absorption ratio depends upon the SB structure. Glycosphingolipids exhibit lower digestion than do phosphosphingolipids, and plant- and fungi-specific SBs exhibit lower absorption than does SB d18: $1^{4 t}$ from animals. Nelson previously reported that when SM with labeled d18: $1^{4 t}$ was administered to rats, approximately $8 \%$ and $20 \%$ of administered radioactivity levels were observed in lymph collected during a $24 \mathrm{~h}$ period and in feces collected for 4 days, respectively [39]. In contrast, administration of GlcCer with labeled d18: $1^{4 t}$ resulted in approximately $4 \%$ and $40 \%$ radioactivity found in lymph and feces, respectively [40]. The digestive enzymes easily hydrolyzed SM and GlcCer with palmitate compared to those bearing longer chains [46,47]. The absorption and metabolism characteristics of free $\mathrm{d} 18: 1^{4 t}$ were similar to those of SM with d18:1 $1^{4 t}$. Conversely, free d18:0 exhibited a much higher absorption ratio than did free $\mathrm{d} 18: 1^{4 t}$; however, the majority of the d18:0 absorbed into the lymph was used for triglyceride synthesis, and, based on this, the level of d18:0 incorporated into sphingolipids was almost equal to that of $\mathrm{d} 18: 1^{4 t}$. Sugawara et al. studied an intestinal tract in vitro model and reported that plant- and fungi-specific SBs (i.e., d18:1 ${ }^{8 c}, \mathrm{~d} 18: 1^{8 t}, \mathrm{~d} 18: 2^{4 t, 8 c}$, $\mathrm{d} 18: 2^{4 t, 8 t}, 9-\mathrm{Me} \mathrm{d} 18: 2^{4 t, 8 t}$, and d18:0) exhibited much lower absorption ratios as free SBs compared to those of the primary animal SB d18:1 ${ }^{4 t}$ due to the efflux of plant and fungal SBs by P-glycoprotein [48-50], and they confirmed that d18:2 ${ }^{4 t, 8 c}$ as the major SB in rice and maize exhibited lower absorption into rat lymph than did d18: $1^{4 t}$ due to efflux. Among the polyunsaturated SBs (i.e., d18:2 $2^{4 t, 8 c}$, d18:2 $2^{4 t, 8 t}$, d18:3 $3^{4 t, 8 t, 10 t}, 9-\mathrm{Me} \mathrm{d} 18: 2^{4 t, 8 t}$, and 9-Me d18:3 $\left.3^{4 t, 8 t, 10 t}\right), \mathrm{d} 18: 2^{4 t, 8 c}$ has been reported to be the SB that is most incorporated into generated sphingolipids in rat lymph [33].

\section{Suppression of Intestinal Cancer by Dietary Sphingolipids}

It has been reported that colon cancer alters sphingolipid metabolism [51]. Due to the decreased cellular levels of Cer that inhibit the cell cycle and induce apoptosis, a reduction in SMase and glycosylceramidase and an increase in SM synthase and GlcCer synthase are both observed in colon cancer cells. Anti-cancer agents and $\gamma$-radiation used for cancer therapy exert opposite effects on these enzymes. Dietary complex sphingolipids have been reported to exert suppressive effects on colon cancer in rodent models. To prepare these models, intraperitoneal (i.p.) injection of 1,2-dimethylhydrazine (DMH) and azoxymethane (AOM) are often used. $\mathrm{DMH}$ is metabolized into $\mathrm{AOM}$, and this compound can act as a carcinogen, particularly in the colon. DMH induces an increase in SM levels and decrease in alk-SMase expression in the colon mucosa [51,52].

\subsection{Sphingomyelin}

Schmelz et al. characterized the chemotherapeutic effects of SM in regard to colon cancer in detail. After an interval of 1 week following DMH treatment, feeding mice a diet containing $0.1 \%$ milk-derived SM for 4 weeks alleviated the formation of aberrant crypt foci (ACF), which are the earliest visible changes involved in the formation of colon cancer, in the colons of these mice [53]. Low SM intake $(0.025 \%$ and $0.05 \%)$ for 34 weeks after the interval did not affect tumor incidence in the colons of DMH-treated mice; however, it did suppress the progression of adenomas into adenocarcinomas. When 
comparing the milk-derived SM, synthetic SM ( $N$-palmitoylsphingomyelin; C16-d18: $1^{4 t}$ with phosphocholine), and synthetic dihydroSM (C16-d18:0 with phosphocholine), it was observed that all SMs suppressed DMH-induced ACF formation and that the effect of dihydroSM was greater than those of the other SMs [54]. SM exhibits a therapeutic effect even if the SB structure is different, and differences in SB structures can affect the intensities. The chemopreventive and chemotherapeutic effects of SM were also investigated under conditions that included $0.05 \%$ SM feeding for 7 weeks starting from 1 week prior to $\mathrm{DMH}$ treatment and feeding for 45 weeks beginning from an interval of 1 week after treatment [55]. Both approaches suppressed the formation and progression of tumors and canceled DMH-inhibited apoptosis in the crypts.

For aging rats (54 weeks of age) that were treated with AOM, daily administration of SM ( $35 \mathrm{mg} / \mathrm{kg}$ body weight) for 6 weeks after an interval of 6 weeks suppressed ACF formation in the proximal region; however, SM feeding did not affect the AOM-mediated decrease in NK cell activity [56]. SM also suppressed ACF formation in aging rats that were not treated with AOM. To compare the effects of dietary SM in the context of $p 53$ deficiency, wild-type and $p 53$ mutant mice were treated with AOM to investigate the relationship between SM feeding and the tumor suppressor gene $p 53$. The results indicated that a $0.1 \%$ SM diet for 4 weeks inhibited cell proliferation but did not induce apoptosis in the distal colon of both types of AOM-treated mice [57]. Feeding of a 0.05\% SM diet for 33-38 weeks also suppressed cell proliferation in the distal colon and tumor. Loss of $p 53$ did not affect SM-inhibited cell proliferation.

Dietary SM exerts chemopreventive and chemotherapeutic effects in the context of colon cancer. Upon SM intake, SM and the fragments that include Cer and SB can reach the large intestine [39]. Continuous SM intake increased the activities of neutral- and alk-SMase in the small and large intestine, and SM intake reversed DMH-reduced colonic alk-SMase expression [51,52]. Therefore, the increase in the colonic levels of bioactive molecules Cer and $\mathrm{SB}$ is speculated to function as a protective mechanism of dietary SM.

\subsection{Glycosphingolipids}

Schmelz et al. also reported the chemotherapeutic effects of glycosphingolipids on colon cancer [46]. DMH-induced ACF formation was suppressed by $0.1 \%$ and $0.025 \%$ diets of GlcCer, LacCer, and GD3 in milk when fed for 4 weeks. Additionally, DMH-induced cell proliferation in crypts was reduced by dietary glycosphingolipids. These effects were the same as those of the milk-derived and synthetic SMs. These milk-derived sphingolipids were partially digested to generate Cer by incubation along with the colon tissue and enteric bacteria. The primary SB in milk-derived sphingolipids was d18: $1^{4 t}$.

We investigated the chemopreventive effects of GlcCer, and we also determined the SB structure [58]. Ten days prior to DMH treatment for 10 weeks, mice were fed $0.1 \%$ and $0.5 \%$ diets of maize-derived GlcCer that predominantly contained SB d $18: 2^{4 t, 8 c}$ and a $0.1 \%$ diet of GlcCer from yeast (Saccharomyces kluyveri) that primarily contained the SB 9-Me d18:2 ${ }^{4 t, 8 t}$. All diets alleviated ACF formation, and the suppressive effects were essentially equal among the three groups. GlcCer bearing $\mathrm{d} 18: 2^{4 t, 8 c}$ was found in the feces and colon mucosa of mice that were fed maize-derived GlcCer. Higher GlcCer concentrations within the diet resulted in higher GlcCer levels in the mouse feces. To clarify the suppressive mechanism of dietary GlcCer, DNA microarray and quantitative RT-PCR analyses were performed on the colon mucosa of mice that were fed $0.1 \%$ maize-derived GlcCer from 10 days prior to DMH treatment for 10 weeks [59]. GlcCer feeding increased the expression of Soggy-1 mRNA, which suppressed the Wnt signaling pathway and decreased the expression of Ras-associated protein to induce the Ras pathway; however, no significant increases were observed in the expression of the genes, such as those of the caspase family, that induce apoptosis directly, thus suggesting that dietary GlcCer regulates cell proliferation and differentiation to prevent the development of ACF in the colon. Moreover, we investigated the effects of GlcCer feeding on colon inflammation following DMH treatment [60]. Mice were fed $0.1 \%$ maize-derived GlcCer 10 days prior to DMH treatment for 7 weeks. Antibody 
array analysis of inflammation-related cytokines revealed that DMH treatment increased the production of inflammatory cytokines and chemokines in the colon, while dietary maize-derived GlcCer suppressed the increased production, particularly for interferon- $\gamma$ (IFN- $\gamma$ )-related factors that included IFN- $\gamma$-induced protein 10 and monokine induced by IFN- $\gamma$.

When focusing on the chemopreventive mechanism of GlcCer, proliferation and apoptosis markers were examined in DMH-induced mutant crypts [61]. DMH-treated rats were fed $0.02 \%$ and $0.1 \%$ diets of rice bran-derived GlcCer that primarily contained the SB $\mathrm{d} 18: 2^{4 t, 8 c}$ for 5 weeks from 1 week prior to DMH treatment. GlcCer feeding suppressed the colonic formation of ACF and $\beta$-catenin-accumulated crypts. Moreover, GlcCer decreased the ratio of proliferation hallmarks in ACF and $\beta$-catenin-accumulated crypts but did not affect the ratio of apoptosis hallmarks in these crypts.

Dietary soybean-derived GlcCer that primarily contains the SB d18:2 $2^{4 t, 8 t}$ has also been reported to exert chemotherapeutic effects [62]. Feeding mice $0.1 \%$ and $0.025 \%$ diets of soybean-derived GlcCer for 4 weeks suppressed DMH-induced ACF formation and the ratio of proliferation-positive cells in the crypt in the colons of these mice. Additionally, when examining mice of the multiple intestinal neoplasia (Min) strain that possess a mutation in the adenomatous polyposis coli (APC) gene, GlcCer was found to affect spontaneous tumorigenesis. Min mice were fed $0.1 \%$ and $0.025 \%$ diets of soybean-derived GlcCer for 8 weeks. Dietary GlcCer intake reduced tumor proliferation in the small intestine in a dose-dependent manner and suppressed mRNA expression of the Wnt signaling pathwayrelated gene TCF4 and the angiogenesis-related gene HIF1- $\alpha$ in the intestinal mucosa.

Glycosphingolipids exert suppressive effects on colon cancer regardless of their polar head groups and SB composition. These effects may result from anti-proliferation activities via anti-inflammatory effects. Epidemiological studies have demonstrated that colon inflammation increases the incidence of colon cancer and that long-term inflammation stress induces cell dedifferentiation [2-4]. Glycosphingolipids exhibit lower digestion in the small intestine compared to that of phosphosphingolipids such as SM; however, they exhibit higher digestion in the large intestine that is facilitated by enteric bacteria and by intestinal digestive enzymes [39,40]. The suppressive effects on colon cancer by dietary glycosphingolipids have been observed to be similar, and dietary Cer intake was demonstrated to suppress intestinal tumor formation in Min mice, as described later [63].

\subsection{Cer and $S B$}

When comparing the effects of dietary Cer ( $N$-palmitoylsphingosine; C16-d18: $\left.1^{4 t}\right)$, milk-derived complex sphingolipids (65\% SM, 7.5\% GlcCer, 20\% LacCer, and 7.5\% GD3 by weight), and their combination (Cer/complex sphingolipids $=40 / 60)$ on intestinal cancer using Min mice with a truncated APC gene product, all of these diets at $0.1 \%$ for 8 weeks were demonstrated to suppress intestinal tumor formation. Their combination exhibited the highest efficacy, and Cer exerted a better effect on the small intestine and lesser effect on the colon compared to the effects of complex sphingolipids [63]. Additionally, administration of $0.025 \%$ and $0.1 \%$ diets containing the sphingoid base analog $(2 \mathrm{~S}, 3 \mathrm{~S}, 5 \mathrm{~S})$ 2-amino-3,5-dihydroxyoctadecane (Enigmol) for 6 weeks suppressed tumor formation in the small intestine of Min mice [64]. Dietary sphingolipids normalized abnormal $\beta$ catenin distribution and cell proliferation in the intestinal epithelial cells of Min mice. The functional components of dietary sphingolipids were confirmed to be Cer and SB. When targeting colon cancer, complex sphingolipids that can reach the colon are more effective than Cer and SB, and complex sphingolipids themselves may also facilitate intestinal protection.

\subsection{Foods Containing Sphingolipids}

To examine the effects of food materials containing sphingolipids on DMH-treated mice, mice were fed diets containing $10 \%$ dried whole milk, $10 \%$ dried maitake mushroom (Grifola frondosa), a 10\% combination of these ingredients (each 5\%), and a $20 \%$ 
combination of these ingredients (each 10\%) from 1 week prior to DMH treatment for 10 weeks [65,66]. Milk sphingolipids comprise SM, LacCer, GlcCer, gangliosides, and Cer [9], while maitake mushroom sphingolipids comprise GlcCer, di-glycosyl Cer, Cer, and acidic sphingolipids [28]. Dried whole milk and maitake mushroom led to the suppression of ACF formation by all experimental diets; however, other parameters differed depending on the diet. Diets containing $10 \%$ milk and those containing a $20 \%$ combination markedly decreased DMH-elevated levels of TNF- $\alpha$ to untreated levels, while the $10 \%$ mushroom and $20 \%$ combination diets decreased the production of anti-apoptotic proteins and increased cleaved caspase-3 production. $\mathrm{DMH}$ treatment increased cecum $\mathrm{pH}$ and decreased the cecum contents of short chain fatty acids, while the $10 \%$ mushroom and $20 \%$ combination diets regulated DMH-modified cecum conditions. Diets containing milk resulted in anti-inflammation activities that were similar to those observed in a previous study on complex sphingolipids [60]; however, diets containing mushroom did not alter these activities in a detectable manner. Mushrooms and plants possessing cell walls may exhibit low availabilities of sphingolipids that form cell membranes. However, mushrooms and plants induce apoptosis of abnormal crypts [67], and, therefore, these materials are expected to exert beneficial effects in combination with animal food materials that contain high contents of sphingolipids.

To evaluate the above hypothesis that animals may not be able to utilize sphingolipids contained in foods of fungi and plant origin due to the presence of cell walls, we investigated whether dietary polished rice (RF) and its ethanol extract (RE), both of which contain the same level of GlcCer, can improve intestinal disease, and we also sought to determine if these effects depend upon the existence of GlcCer [68]. Mice were fed an $\mathrm{RF}$ diet (RF $150 \mathrm{~g} / \mathrm{kg}$ diet) and RE diet (RE $0.5 \mathrm{~g}$ extracted from RF $150 \mathrm{~g} / \mathrm{kg}$ diet) from 2 weeks prior to DMH treatment for 7 weeks. GlcCer contents were nearly identical in the $\mathrm{RF}$ and RE diets (3.0 and $2.7 \mathrm{mg} / \mathrm{kg}$, respectively). Dietary RF and RE intake suppressed $\mathrm{DMH}$-induced ACF formation, and RE in particular exhibited a significant suppressive effect. Dietary RE inhibited the DMH-induced production of almost all of the inflammationrelated cytokines studied, while RF suppressed significantly fewer of these cytokines. Rice also contains Cer, GIPC, and oligo-glycosyl Cer $[23,27]$. It has been suggested that the lipophilic fraction containing sphingolipids in plant- and fungi-derived foods exerts protective effects against intestinal impairment; however, this fraction requires extraction, as digestion alone is not sufficient to induce its full protective action.

Subsequently, to clarify whether changes in sphingolipid composition in foods subjected to fermentation affect intestinal protection, mice were fed a sake rice extract diet $(0.9 \mathrm{~g}$ extracted from sake rice $150 \mathrm{~g} / \mathrm{kg}$ diet) or a sake lees extract diet $(42.1 \mathrm{~g}$ extracted from sake lees $150 \mathrm{~g} / \mathrm{kg}$ diet) from 2 weeks prior to DMH treatment for 7 weeks [69]. Sake lees are byproducts of brewed sake (rice wine), and the lipophilic compounds are concentrated compared to sake rice used as the raw material; however, the levels of highly polar sphingolipids, including GIPC, are markedly decreased and the levels of free Cer and free SB are markedly increased in sake lees [22,23]. Both diets suppressed DMH-induced ACF formation, the production of TNF- $\alpha$ and apoptosis-related proteins, and the oxidation of colon mucosa. Change in sphingolipid composition before and after fermentation are not believed to affect intestinal protection. The impacts of dietary sphingolipids on DMH-treated rodents are summarized in Table 3. 
Table 3. Suppression and the mechanism of DMH-induced ACF formation by dietary sphingolipids.

\begin{tabular}{|c|c|c|c|c|c|}
\hline Diet* & Animal & Diet Duration & DMH Treatment & Effects & Refs. \\
\hline $0.1 \%$ buttermilk- and powdered milk-derived SM & \multirow{2}{*}{ Female CF1 mice6 wks of age } & $\begin{array}{l}\text { For } 4 \text { wks from } 1 \text { wk } \\
\text { after final DMH i.p. }\end{array}$ & $\begin{array}{l}\text { Once i.p. per wk for } 6 \text { wks } \\
40 \mathrm{mg} / \mathrm{kg} \mathrm{bw}\end{array}$ & ACF formation $\downarrow$ & \multirow{2}{*}{ [53] } \\
\hline $0.025 \%, 0.05 \%$, and $0.1 \%$ buttermilk-derived SM & & $\begin{array}{l}\text { For } 34 \mathrm{wks} \text { from } 1 \mathrm{wk} \\
\text { after final DMH i.p. }\end{array}$ & $\begin{array}{l}\text { Once i.p. per } \mathrm{wk} \text { for } 6 \text { wks } \\
20 \mathrm{mg} / \mathrm{kg} \mathrm{bw}\end{array}$ & $\begin{array}{l}\text { Colonic tumor incidence } \leftrightarrow ; \text { Adenoma progression } \\
\text { to adenocarcinoma } \downarrow\end{array}$ & \\
\hline $\begin{array}{l}0.1 \% \text { milk-derived SM, synthetic SM (C16-118:14t), } \\
\text { and dihydoSM (C16-d18:0) }\end{array}$ & $\begin{array}{l}\text { Female CF1 mice } \\
6 \text { wks of age }\end{array}$ & $\begin{array}{l}\text { For 4wks from } 1 \mathrm{wk} \\
\text { after final DMH i.p. }\end{array}$ & $\begin{array}{l}\text { Once i.p. per wk for } 6 \text { wks } \\
40 \mathrm{mg} / \mathrm{kg} \mathrm{bw}\end{array}$ & ACF formation $\downarrow$ & [54] \\
\hline $\begin{array}{l}0.025 \% \text { and } 0.1 \% \text { syntetic glucuronylceramide } \\
\left(\mathrm{C} 16-\mathrm{d} 18: 1^{4 t}\right)\end{array}$ & $\begin{array}{l}\text { Female CF1 mice } \\
6 \text { wks of age }\end{array}$ & $\begin{array}{l}\text { For } 4 \text { wks from } 1 \mathrm{wk} \\
\text { after final DMH i.p. }\end{array}$ & $\begin{array}{l}\text { Once i.p. per wk for } 6 \text { wks } \\
30 \mathrm{mg} / \mathrm{kg} \text { bw }\end{array}$ & ACF formation $\downarrow$ & [70] \\
\hline $\begin{array}{l}0.025 \% \text { and } 0.1 \% \text { milk-derived GlcCer, LacCer, } \\
\text { and ganglioside (GD3) }\end{array}$ & $\begin{array}{l}\text { Female CF1 mice } \\
6 \text { wks of age }\end{array}$ & $\begin{array}{l}\text { For } 4 \text { wks from } 1 \mathrm{wk} \\
\text { after final DMH i.p. }\end{array}$ & $\begin{array}{l}\text { Once i.p. per wk for } 6 \mathrm{wks} \\
30 \mathrm{mg} / \mathrm{kg} \text { bw }\end{array}$ & $\begin{array}{c}\text { ACF formation } \downarrow \text {; Cell prolififartion in crypt } \downarrow \text { (these } \\
0.1 \% \text { milk-data also contained } \\
\text { cond synthetic SM diets) }\end{array}$ & [46] \\
\hline \multirow{2}{*}{$0.05 \%$ milk-derived SM } & $\begin{array}{l}\text { Female CF1 mice } \\
5 \text { wks of age }\end{array}$ & $\begin{array}{l}\text { For } 7 \mathrm{wks} \text { from } 1 \mathrm{wk} \\
\text { prior to first DMH i.p. }\end{array}$ & $\begin{array}{l}\text { Once i.p. per wk for } 6 \text { wks } \\
30 \mathrm{mg} / \mathrm{kg} \mathrm{bw}\end{array}$ & $\begin{array}{l}\text { Colonic tumor incidence } \downarrow \text {; Adenoma and } \\
\text { carcinoma }\end{array}$ & \multirow{2}{*}{ [55] } \\
\hline & $\begin{array}{l}\text { Female CF1 mice } \\
6 \text { wks of age }\end{array}$ & $\begin{array}{l}\text { For } 44 \text { wks from } 1 \text { wk } \\
\text { after final DMH i.p. }\end{array}$ & $\begin{array}{l}\text { Once i.p. per wk for } 6 \text { wks } \\
30 \mathrm{mg} / \mathrm{kg} \text { bw }\end{array}$ & $\begin{array}{c}\text { Cell proliferation in crypt } \downarrow ; \text { A Apoptotic inhibition in } \\
\text { crypts } \downarrow\end{array}$ & \\
\hline $0.05 \%$ milk-derived SM based on AIN-93 & $\begin{array}{l}\text { Female ICR mice } \\
5 \mathrm{wks} \text { of age }\end{array}$ & $\begin{array}{c}\text { For } 22 \text { wks after final } \\
\text { DMH i.p. }\end{array}$ & $\begin{array}{l}\text { Once i.p. per wk for } 6 \text { wks } \\
\quad 30 \mathrm{mg} / \mathrm{kg} \mathrm{bw}\end{array}$ & $\begin{array}{c}\text { Colonic tumor formation } \downarrow \text {; Colonic expression and } \\
\text { production of alk-SMase } \\
\text { Alk-SMase activity in colon mucosa } \\
\text { activity in colon content } \Leftrightarrow\end{array}$ & [52] \\
\hline $\begin{array}{l}0.1 \% \text { and } 0.5 \% \text { maize-derived GlcCer } \\
\text { and } 0.1 \% \text { yeast-derived GlcCer }\end{array}$ & $\begin{array}{l}\text { Male BALB/c mice } \\
5 \text { wks of age }\end{array}$ & $\begin{array}{l}\text { For } 80 \mathrm{ds} \text { from } 10 \mathrm{ds} \\
\text { before firt DMH i.p. }\end{array}$ & $\begin{array}{l}\text { Once i.p.p per wk for } 10 \text { wks } \\
15 \mathrm{mg} / \mathrm{kg} b \mathrm{bw}\end{array}$ & ACF formation $\downarrow$ & [58] \\
\hline $0.1 \%$ maize-derived GlcCer & $\begin{array}{c}\text { Male BALB/c mice } \\
5 \mathrm{wks} \text { of age }\end{array}$ & $\begin{array}{l}\text { For } 80 \mathrm{ds} \text { from } 10 \mathrm{ds} \\
\text { prior to first DMH i.p. }\end{array}$ & $\begin{array}{l}\text { Once i.p. per wk for } 10 \text { wks } \\
15 \mathrm{mg} / \mathrm{kg} \mathrm{bw}\end{array}$ & 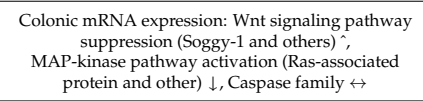 & [59] \\
\hline $0.02 \%$ and $0.1 \%$ rice-derived Glccer based on CE- 2 & $\begin{array}{l}\text { Male F344 rats } \\
42 \text { wks of age }\end{array}$ & $\begin{array}{l}\text { For } 5 \mathrm{wks} \text { from } 1 \mathrm{wk} \\
\text { prior to first DMH i.p. }\end{array}$ & $\begin{array}{l}\text { Once i.p. per } 2 \text { wks for } 4 \text { wks } \\
\quad 40 \mathrm{mg} / \mathrm{kg} \text { bw }\end{array}$ & $\begin{array}{c}\text { ACF and BCAC formation } \downarrow ; \\
\text { Cell proliferation in ACF and BCAC } \downarrow ; \text { Cell } \\
\text { apoptosis in ACF and BCAC } \leftrightarrow\end{array}$ & [61] \\
\hline $15 \%$ polished rice and $0.05 \%$ rice extract & $\begin{array}{l}\text { Male BALB/c mice } \\
5 \text { wks of age }\end{array}$ & $\begin{array}{l}\text { For } 9 \mathrm{wks} \text { from } 2 \mathrm{wks} \\
\text { prior to first DMH i.p. }\end{array}$ & $\begin{array}{l}\text { Once i.p. per wk for } 7 \mathrm{wks} \\
15 \mathrm{mg} / \mathrm{kg} \mathrm{bw}\end{array}$ & 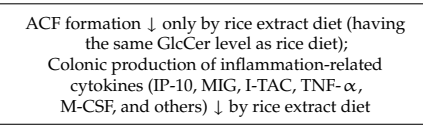 & [68] \\
\hline $0.09 \%$ sake rice extract and $4.21 \%$ sake lees extract & $\begin{array}{c}\text { Male BALB/c mice } \\
5 \mathrm{wks} \text { of age }\end{array}$ & $\begin{array}{l}\text { For } 9 \text { wks from } 2 \text { wks } \\
\text { prior to first DMH i.p. }\end{array}$ & $\begin{array}{l}\text { Once i.p. per wk for } 7 \text { wks } \\
15 \mathrm{mg} / \mathrm{kg} \text { bw }\end{array}$ & $\begin{array}{l}\text { ACF formation } \downarrow ; \text { Colonic inflammation and } \\
\text { oxidation (TNF- } \alpha \text { and malondialdehyde) } \downarrow \text {; } \\
\text { Colonic production of apoptosis-related proteins } \\
\text { (Bcl-2, cleaved caspase-3, and others) } \downarrow\end{array}$ & [69] \\
\hline
\end{tabular}

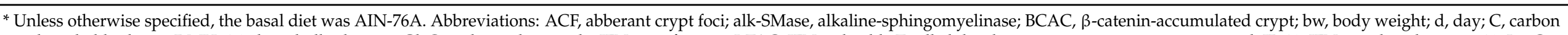

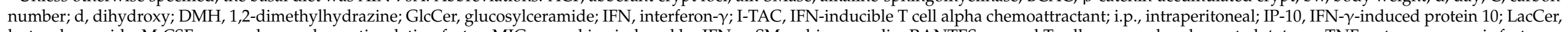

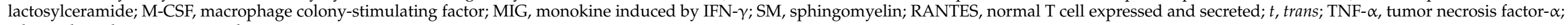
wk, week; $\downarrow$, decrease; $\leftrightarrow$, no change; ${ }^{\wedge}$ increase 


\subsection{Apoptotic and Anti-Proliferative Effects of Sphingolipids on Colon Cancer Cells}

Dietary sphingolipids are partially digested by intestinal enzymes and enteric bacteria into Cer and SB in the intestine. Exogenous Cer and SB induce apoptosis in various cancer cells, including colon cancer cells. Cer-bearing short-chain fatty acids (C2 to C8) are often used for experiments due to their cell permeability, while sphingolipids possessing long-chain fatty acids (C14 to C26) or hydroxy fatty acids are contained in foods.

The addition of $\mathrm{d} 18: 1^{4 t}$ and $\mathrm{d} 18: 0$ as free SB and of $\mathrm{C} 2$-d $18: 1^{4 t}$ as Cer induced apoptosis and arrested the cell cycle in the $\mathrm{G}_{2} / \mathrm{M}$ phase in human colon cancer cells (HT29 and HCT116), while treatment with dihydroCer (C2-d18:0) did not induce apoptosis and cell cycle arrest [71,72]. Compared to free SBs (d18:14t $\mathrm{t} 18: 0, \mathrm{~d} 18: 1^{8 c}, \mathrm{~d} 18: 1^{8 t}, \mathrm{~d} 18: 2^{4 t, 8 c}, \mathrm{~d} 18: 2^{4 t, 8 t}$, $\mathrm{d} 18: 3^{4 t, 8 t, 10 t}, 9-\mathrm{Me} \mathrm{d} 18: 2^{4 t, 8 t}$, and 9-Me d18:34t,8t,10t$)$, all of the SBs used in these experiments exhibited apoptotic effects on human colon cancer cells (DLD-1, Caco-2, and WiDr), but not in normal intestinal cells $[29,73,74]$. SB induced a decrease in intracellular $\beta$-catenin levels in colon cancer cells. The apoptotic effect of C6-d18: $1^{4 t}$ was enhanced in colon cancer cells (HCT-15, HT-29, and LoVo) by treatment with P-glycoprotein inhibitors (tamoxifen, cyclosporine A, biricodar, and verapamil) [75]. Co-treatment of C6-d18: $1^{4 t}$ with tamoxifen increased intracellular Cer levels, decreased GlcCer levels, and induced apoptosis in a manner that was independent of $p 53$. Conversely, low levels of natural Cer possessing long-chain fatty acids from the bovine brain reduced cytosolic $\beta$-catenin levels in colon cancer cells (SW480), while C2-d18: $1^{4 t}$ did not reduce these levels [63].

Various SBs from foods exert similar levels of apoptotic induction in colon cancer cells $[29,73,74]$; however, SBs with different structures exhibit the same absorption but different efflux characteristics in intestinal cells $[48,49]$. Therefore, SB efflux in colon cancer cells may differ from that in normal intestinal cells, and SBs may act immediately. Additionally, Cer-bearing long-chain fatty acids from foods exhibit low permeability; however, food-derived Cer may suppress the proliferating ability of colon cancer cells even at low concentrations $(2.5 \mu \mathrm{M})$ compared to this ability of Cer-bearing short-chain fatty acids that exhibit high permeability [63]. DihydroCer-bearing short-chain fatty acids have been used in apoptosis and permeability experiments as the negative control [71,72]; however, when endogenous dihydroCer is accumulated by knockout or treatment with an inhibitor of dihydroCer desaturase, the proliferation of cancer cells is suppressed [76]. Additionally, as dietary dihydroSM treatment exerted the inhibition of the formation of ACF in DMH-treated mice compared to that of SM [54], further studies are required to confirm the effects of food-derived Cer possessing different SBs on colon cancer cells.

\section{Suppression of Intestinal Inflammation by Dietary Sphingolipids}

IBD is a form of refractory enteritis, and chronic colon inflammation increases the risk of the onset of colon cancer. Regulation of sphingolipid metabolism is an attractive therapeutic target for colitis diseases, including IBD. The colon mucosa of patients with IBD has been reported to increase the level of sphingosine kinase 1, an enzyme that phosphorylates SB to sphingosine1-phosphate (S1P) [77]. Experimental rodent models are often prepared by the administration of dextran sodium sulfate (DSS), which induces a direct injury of intestinal mucosa and inflammation via activation of $\mathrm{T}$ lymphocytes. Knockout or inhibitors of sphingosine kinase 1 resulted in reduced immune responses during colitis in DSS-treated mice [77,78]. Inflammatory cytokines, including TNF- $\alpha$ and IL1 $\beta$, activated SMase activity [79] and DSS treatment increased Cer levels within the colon [80]. Deficiency in Cer synthase 6, an enzyme that generates C14- and C16-Cer from $\mathrm{SB}$, protected against the development of colitis induced by an adoptive transfer method [81].

\subsection{Sphingomyelin}

Dietary SM has been reported to suppress and to stimulate colon inflammation. In a study examining the suppressive effects, mice were fed $0.1 \% \mathrm{SM}$ (origin-unknown) from 3 days prior to $2 \%$ DSS treatment for 1 week, and SM feeding suppressed body weight 
loss, colon injury, and colon myeloperoxidase (MPO) activity (an indicator of neutrophil invasion) in DSS-treated mice and promoted IgA secretion into the large intestine in nonDSS-treated mice [82]. In contrast, in a study examining inflammation acceleration, mice received egg yolk-derived SM via oral gavage in combination with $2 \%$ DSS treatment for $7 \mathrm{~d}$. SM doses of $4 \mathrm{mg}$ or $8 \mathrm{mg} /$ day (calculated as $0.1 \%$ or $0.2 \%$ of the total daily food intake) and SM administration accelerated body weight loss, colon injury, and intestinal epithelial cell apoptosis in DSS-treated mice [83]. SM administration also increased Cer content and activated caspase- 3 and 9 via cathepsin D in intestinal epithelial cells. Additionally, IL-10 negative mice used as a spontaneous colitis model were gavaged with $4 \mathrm{mg}$ of egg yolk-derived SM/day for 30 days, and SM administration accelerated body weight loss and colon injury.

Another study reported the effects of dietary SM on inflammation-related colon cancer induced by treatment with DSS in combination with AOM [84]. Mice with/without PPAR$\gamma$ deficiency only in epithelial and hematopoietic cells were fed a $0.1 \%$ milk-derived SM diet and received an AOM injection on the 7th day. Drinking water was changed to that containing $2 \%$ DSS on the 13th day, and DSS water was returned to normal water at the 20th day. Dietary SM suppressed colonic inflammatory lesions and subsequently shortened inflammatory recovery time, particularly in PPAR- $\gamma$ expressing mice. Additionally, dietary SM increased the survival ratio and suppressed tumor formation, in both PPAR- $\gamma$-deficient and expressing mice, at 80 days after $\mathrm{AOM}$ injection.

Differences in the inflammation stage or SM structure may determine whether dietary SM exerts beneficial or unfavorable effects in the context of colon inflammation. Inflammation affects the intestinal barrier and sphingolipid metabolism, and Cer synthase deficiency and SMase inhibitors suppress colon inflammation in experimental colitis [81,85]. Additionally, the accumulation of endogenous Cer, especially C16-d18: $1^{4 t}$, accelerates inflammation via apoptosis [86,87]. In general, SM and Cer possessing long-chain fatty acids exhibit low permeability into intestinal cells; however, they can penetrate under barrier impairment. In regard to SM structure, the fatty acid composition of egg yolk-derived SM is predominantly $\mathrm{C} 16$, while that of milk-derived SM possesses longer chains (C23, C22, and C24), as shown in Table 1 [34]. C16-SM is more easily digested by SMase compared to SM-bearing longer chains [46]. Thus, egg yolk SM may be more easily absorbed as Cer forms into intestinal cells compared to the absorption of milk-derived SM.

\subsection{Glycosphingolipids}

To the best of our knowledge, there is only one report regarding the beneficial effects of dietary GlcCer on DSS-induced colitis [88]. Mice were fed a 0.1\% maize-derived GlcCer diet at 3 days prior to DSS treatment for 14 days. Colon samples on the 5th and 15th days after the switch to $2 \%$ DSS drinking water were used for cytokine analysis and histological analysis, respectively. Dietary GlcCer exposure alleviated weight loss during DSS treatment and preserved the integrity of the colon epithelium. DSS treatment increased the colon level of MPO and the production of inflammatory cytokines and chemokines including IFN- $\gamma$, IP-10, and MIG in the colon, and dietary GlcCer suppressed their inflammatory impairment. As described above (Section 5.2), dietary maize-derived GlcCer alleviated DMH-induced colon inflammation [60]. Maize-derived GlcCer comprises 2-hydroxy longchain fatty acids (hydroxy C20, C24, and C22), as shown in Table 2 [26], and, therefore, it may be difficult to digest and absorb as Cer forms compared to the digestion of complex sphingolipids bearing shorter chains $[46,47]$.

Dietary ganglioside has been reported to protect against small intestinal inflammation induced by high-fat diet and lipopolysaccharide (LPS) treatment $[89,90]$. Rats were fed a $20 \%$ high-fat ( $w t \%$; adjusted by triglyceride) diet containing $0.02 \%$ milk-derived gangliosides (primarily GD3) for 2 weeks and then subsequently treated with i.p. LPS. Six hours after LPS treatment, dietary ganglioside exposure resulted in lower levels of IL-1 $\beta$ and TNF$\alpha$ as inflammatory cytokines and a higher level of IL-10 as an anti-inflammatory cytokine in intestinal mucosa and plasma and suppressed the LPS-induced expression decrease in the 
intestinal tight junction protein occlusion and intestinal villi damage. The change in food style from a carbohydrate-based diet to a diet containing high fat has been suggested to cause an increase in IBD incidence rates in East Asia [2-4] due to intestinal barrier weakening and abnormal host immune responses to the enteric bacteria $[6,91]$. As described below (Sections 7 and 8), dietary complex sphingolipids improve lipid metabolism, intestinal tight junctions, and enteric bacteria flora.

\subsection{Extracts Containing Sphingolipids from Foods}

The beneficial effects of a sphingolipid-rich fraction from mushrooms on DSS-induced colitis have been demonstrated $[92,93]$. The sphingolipid-rich fraction of mushrooms was prepared by ethanol extraction from the residue after hot-water extraction of golden oyster mushroom (Pleurotus citrinopileatus). Mice were fed $1 \%$ or $5 \%$ mushroom extract diets 10 days prior to DSS treatment for 25 days. Colon samples on the 18th and 26th days from the switch to $1.5 \%$ DSS drinking water were used for cytokine analysis and histological analysis, respectively. Dietary mushroom extract suppressed DSS-induced body weight loss, colon length reduction, and spleen weight. Dietary mushroom extract ameliorated colon villi damage and increased the production of inflammation-related cytokines in a dose-dependent manner. Moreover, the mushroom extract was separated into two fractions containing polar lipids (GlcCer, IPC, and GIPC) and neutral lipids (Cer and free fatty acids) through the use of acetone. Mice were fed 1\% polar lipid or neutral lipid diets from 1 week prior to DSS treatment for 20 days. On the 21st day after the switch to $1.5 \%$ DSS drinking water, dietary mushroom polar lipids improved DSS-induced colon villi damage, while dietary neutral lipids caused the damage to worsen. Using differentiated Caco-2 cells as an intestinal tract in vitro model, the polar lipid fraction suppressed LPS-induced apoptosis, while treatment with the neutral lipid fraction resulted in weaker suppression. Therefore, the consumption of mushroom glycosphingolipids is speculated to contribute to colitis prevention.

\subsection{Effects of Sphingolipids on Ex Vivo and In Vitro Inflammation}

In experiments using bowel tissue obtained from infants requiring open bowel surgery for intestinal atresias, pretreatment with milk-derived ganglioside (primary species GD3) was reported to alleviate LPS-, hypoxia-, and combination-induced inflammation via suppression of inflammatory cytokine production and oxidative stress [94].

Using differentiated Caco-2 cells as a normal human intestinal model, the protective mechanism of complex sphingolipids on inflammation stress was investigated in detail. The addition of TNF- $\alpha$ or LPS to induce inflammatory stress decreased cell viability through the induction of apoptosis. Wheat-derived GlcCer (primarily SB d18:2 ${ }^{8 c}$ ), maizederived GlcCer (primarily d18:24t,8c), and bovine brain-derived GalCer (primarily d18:1 ${ }^{4 t}$ ) suppressed cell injury due to inflammatory stress, and there was no observed difference in these suppressive effects among all complex sphingolipids studied [95]. The production of inflammatory cytokines and chemokines induced by LPS was suppressed by maize-derived GlcCer. Additionally, exogenous maize-derived GlcCer was localized on the cell surface and not in the cytoplasm. Cer (sake lees-derived Cer and C20-d18:1 ${ }^{4 t}$ ) treatment induced apoptosis in differentiated Caco-2 cells under non-stress conditions, and Cer treatment suppressed LPS-induced apoptosis (unpublished data). In contrast, GlcCer, SBs, and S1P were not observed to induce apoptosis under non-stress conditions, and they suppressed LPS-induced apoptosis. These results suggest that GlcCer is non-cytotoxic, accumulates on cell membranes, and is metabolized during inflammation to protect intestinal cells by maintaining sphingolipid levels in cells and producing S1P. Additionally, as highly polar sphingolipids containing GIPC from mushroom suppressed LPS-induced apoptosis to a greater degree compared to the observed suppression by Cer and GlcCer [96], complex sphingolipids may also affect cell membrane functions.

Milk-derived SM suppressed LPS-induced mRNA expression of TNF- $\alpha$ in RAW264.7 macrophages, while SM in combination with SMase inhibitor treatment did not [97]. Cer 
(C16-d18: $1^{4 t}$ and C24-d18: $\left.1^{4 t}\right)$ and free SB (d18:1 $\left.{ }^{4 t}\right)$ also suppressed LPS-induced expression of TNF- $\alpha$, while dihydroCer (C16-d18:0 and C24-d18:0) did not. In contrast, macrophages of SM synthase 2-deficient mice (deficiency of SM bearing very long-chain fatty acids) exhibited decreased sensitivity to thioglycolate and LPS [98]. The sensitivity was recovered by the addition of SM-containing long-chain fatty acids (C16 and C24), particularly C24, but not by the addition of SM with $\mathrm{C} 6$ and Cer with $\mathrm{C} 24$. Additionally, SM synthase 2-deficient mice were reported to be resistant to DSS-induced colitis [80]. These reports indicate that dietary complex sphingolipids can affect intestinal immunity.

\section{Effects of Sphingolipids on Lipid Absorption and Energy Metabolism}

Dietary sphingolipids are known to improve lipid absorption and metabolism. Oral gavage of cholesterol and other lipids inhibited their intestinal absorption into rat lymph in the presence of SM, and the effects of milk-derived SM were higher than those of egg yolk-derived SM [99]. In mice fed a $21 \%$ high-fat diet ( $w \mathrm{t} \%$; adjusted by anhydrous milk fat), consumption of $0.25 \%$ milk-derived SM decreased serum levels of cholesterol and LPS, while consumption of egg yolk-derived SM did not [100]. In in vitro studies using differential Caco-2 cells as an intestinal tract model, the hydrolysis of SM or Cer increased the cholesterol absorption [101,102], while the addition of SB d18:1 ${ }^{4 t}$ reduced the cholesterol absorption and suppressed mRNA expression of the Niemann-Pick C1-Like 1 deeply implicated in cholesterol transport [103]. As shown in Table 1, the SB and fatty acid compositions of milk SM differ from those of egg yolk SM. The differences may affect SM functions via micellar solubilization and affinity with the hydrolases.

In Zucker rats with leptin functional disorder, $0.5 \%$ chicken skin-derived SM and maize-derived GlcCer diets decreased the levels of hepatic lipid and plasma non-HDL cholesterol, and, in particular, dietary GlcCer alleviated the plasma insulin reduction and adiponectin increase [35]. These results, in combination with the results of hepatic gene expression analyses, suggest that dietary sphingolipids improve insulin resistance via hepatic AMPK activation. Dietary sphingolipids were also observed to improve the insulin resistance that was induced in rats by a high-fructose diet $(70 \mathrm{wt} \%$ instead of sucrose and starch; $0.25 \mathrm{mmol} / \mathrm{kg}$ diet of sea cucumber-derived Cer and GlcCer at $0.16 \mathrm{~g}$ and $0.21 \mathrm{~g} / \mathrm{kg}$ diet, respectively) [104]. Interestingly, Cer exerted a stronger effect on glycogen accumulation in skeletal muscle, while GlcCer exhibited higher accumulation in the liver.

\section{Other Beneficial Effects of Dietary Sphingolipids}

There are many reports regarding the benefits of dietary sphingolipids besides those described above, and these benefits include the inhibition of tumor growth and progression in xenograft models of cancer $[105,106]$, selective activation of enteric bacteria $[100,107,108]$, alleviation of atopic dermatitis [109], and improvement of skin barrier functions [110-114]. For example, Cer and complex sphingolipids derived from various foods have been demonstrated to improve the moisture content of the skin according to human and animal studies. Using labeled sphingolipids in rodents, it was revealed that when sphingolipids are orally administered, the SB can reach the skin to be metabolized to Cer and complex sphingolipids [115,116]. According to other in vitro and in vitro studies, dietary complex sphingolipids upregulated Cer synthesis in mouse skin and free SBs derived from plants also upregulated Cer synthesis in keratinocytes compared to the upregulation observed in response to animal SB d18:1 $1^{4 t}[111,117]$. In regard to the effects of dietary sphingolipids on enteric bacteria, Rohrhofer et al. have reviewed this in detail [118].

\section{Conclusions}

Sphingolipids are consumed during every meal. Due to their low intestinal absorption, a great deal of attention has been directed towards the direct effects of Cer and SBs as digests and bioactive molecules. Currently, it has been reported that dietary sphingolipids are beneficial to various body parts, and these effects can be due to the complex sphingolipids themselves and can be modulated by different SB structures. Sphingolipids in foods 
exhibit diverse structures (i.e., polar head groups, SBs, and fatty acids) depending on the source, and, therefore, it is necessary to distinguish between the functions of foodderived and endogenous sphingolipids. There is a possibility that various functions of dietary sphingolipids are exerted by intestinal homeostasis mechanisms such as nutritional absorption, intestinal barrier function, and gut immunity. Further macro- and micro-studies will further clarify the roles of dietary sphingolipids in the near future.

Funding: A portion of this research was supported by The Public Foundation of Elizabeth Arnold-Fuji.

Conflicts of Interest: The authors declare no conflict of interest.

\section{References}

1. Jacobson, A.; Yang, D.; Vella, M.; Chiu, I.M. The intestinal neuro-immune axis: Crosstalk between neurons, immune cells, and microbes. Mucosal Immunol. 2021, 14, 555-565. [CrossRef] [PubMed]

2. Ng, S.C.; Shi, H.Y.; Hamidi, N.; Underwood, F.E.; Tang, W.; Benchimol, E.I.; Panaccione, R.; Ghosh, S.; Wu, J.C.Y.; Chan, F.K.L.; et al. Worldwide incidence and prevalence of inflammatory bowel disease in the 21st century: A systematic review of population-based studies. Lancet 2017, 390, 2769-2778. [CrossRef]

3. Sung, H.; Ferlay, J.; Siegel, R.L.; Laversanne, M.; Soerjomataram, I.; Jemal, A.; Bray, F. Global cancer statistics 2020: GLOBOCAN estimates of incidence and mortality worldwide for 36 cancers in 185 countries. CA Cancer J. Clin. 2021, 71, 209-249. [CrossRef]

4. Triantafillidis, J.K.; Nasioulas, G.; Kosmidis, P.A. Colorectal cancer and inflammatory bowel disease: Epidemiology, risk factors, mechanisms of carcinogenesis and prevention strategies. Anticancer Res. 2009, 29, 2727-2737.

5. Hofmanová, J.; Straková, N.; Vaculová, A.H.; Tylichová, Z.; Šafa, B.; Skender, B.; Kozubík, A. Interaction of dietary fatty acids with tumour necrosis factor family cytokines during colon inflammation and cancer. Mediat. Inflamm. 2014, 2014, 848632. [CrossRef]

6. Maceyka, M.; Spiegel, S. Sphingolipid metabolites in inflammatory disease. Nature 2014, 510, 58-67. [CrossRef] [PubMed]

7. Ogretmen, B. Sphingolipid metabolism in cancer signalling and therapy. Nat. Rev. Cancer 2018, 18, 33-50. [CrossRef]

8. Yamashita, S.; Kikuchi, N.; Kinoshita, M.; Miyazawa, T. Chemical properties and nutritional value of plant-origin glucosylceramide. J. Nutr. Sci. Vitaminol. 2019, 65, S153-S157. [CrossRef]

9. Vesper, H.; Schmelz, E.M.; Nikolova-Karakashian, M.N.; Dillehay, D.L.; Lynch, D.V.; Merrill, A.H., Jr. Sphingolipids in food and the emerging importance of sphingolipids to nutrition. J. Nutr. 1999, 129, 1239-1250. [CrossRef]

10. Okuda, T. Dietary Control of Ganglioside Expression in Mammalian Tissues. Int. J. Mol. Sci. 2019, 21, 177. [CrossRef]

11. Ma, L.; Fong, B.Y.; MacGibbon, A.K.H.; Norris, G. Qualitative and quantitative study of glycosphingolipids in human milk and bovine milk using high performance liquid chromatography-data-dependent acquisition-mass spectrometry. Molecules 2020, 25, 4024. [CrossRef]

12. Hellgren, L.J. Occurrence of bioactive sphingolipids in meat and fish products. Eur. J. Lipid Sci. Technol. 2001, 103, 661-667. [CrossRef]

13. Duan, J.; Sugawara, T.; Hirata, T. Rapid quantitative analysis of sphingolipids in seafood using HPLC with evaporative lightscattering detection: Its application in tissue distribution of sphingolipids in fish. J. Oleo Sci. 2010, 59, 509-513. [CrossRef] [PubMed]

14. Hori, T.; Sugita, M. Sphingolipids in lower animals. Prog. Lipid Res. 1993, 32, 25-45. [CrossRef]

15. Fujino, Y.; Ohnishi, M. Species of sphingolipids in rice grain. Proc. Jpn. Acad. Ser. B Phys. Biol. Sci. 1982, 58, 36-39. [CrossRef]

16. Markham, J.E.; Li, J.; Cahoon, E.B.; Jaworski, J.G. Separation and identification of major plant sphingolipid classes from leaves. J. Biol. Chem. 2006, 281, 22684-22694. [CrossRef]

17. Buré, C.; Cacas, J.L.; Mongrand, S.; Schmitter, J.M. Characterization of glycosyl inositol phosphoryl ceramides from plants and fungi by mass spectrometry. Anal. Bioanal. Chem. 2014, 406, 995-1010. [CrossRef]

18. Kimura, K.; Kinoshita, M.; Takakuwa, N.; Tamura, M.; Oda, Y.; Ohnishi, M. Content and constituent properties of sphingolipid classes in Saccharomyces kluyveri. J. Oleo Sci. 2006, 55, 623-627. [CrossRef]

19. Ogawa, S.; Tachimoto, H.; Kaga, T. Elevation of ceramide in Acetobacter malorum S24 by low pH stress and high temperature stress. J. Biosci. Bioeng. 2010, 109, 32-36. [CrossRef]

20. Okino, N.; Li, M.; Qu, Q.; Nakagawa, T.; Hayashi, Y.; Matsumoto, M.; Ishibashi, Y.; Ito, M. Two bacterial glycosphingolipid synthases responsible for the synthesis of glucuronosylceramide and $\alpha$-galactosylceramide. J. Biol. Chem. 2020, 295, 10709-10725. [CrossRef]

21. Han, C.; Xia, K.; Yang, J.; Zhang, H.; DeLisa, M.P.; Liang, X. Investigation of lipid profile in Acetobacter pasteurianus Ab3 against acetic acid stress during vinegar production. Extremophiles 2020, 24, 909-922. [CrossRef]

22. Yamashita, S.; Higaki, C.; Kanai, A.; Kikuchi, N.; Suzuki, D.; Kinoshita, M.; Miyazawa, T. Sphingolipid properties in sake rice cultivars and changes during polishing and brewing. J. Oleo Sci. 2021, 70, 263-273. [CrossRef]

23. Yamashita, S.; Higaki, C.; Kikuchi, N.; Suzuki, D.; Kinoshita, M.; Miyazawa, T. Sake (rice wine) brewing hydrolyzes highly polar sphingolipids to ceramides and increases free sphingoid bases. J. Oleo Sci. 2021. Preprint. [CrossRef]

24. Omae, F.; Miyazaki, M.; Enomoto, A.; Suzuki, M.; Suzuki, Y.; Suzuki, A. DES2 protein is responsible for phytoceramide biosynthesis in the mouse small intestine. Biochem. J. 2004, 379, 687-695. [CrossRef] 
25. Miyazawa, T.; Ito, S.; Fujino, Y. Isolation of cerebroside from pea seeds. Agric. Biol. Chem. 1974, 38, 1387-1391. [CrossRef]

26. Aida, K.; Takakuwa, N.; Kinoshita, M.; Sugawara, T.; Imai, H.; Ono, J.; Ohnishi, M. Properties and physiological effects of plant cerebroside species as functional lipids. In Advanced Research on Plant Lipids; Murata, N., Ed.; Kluwer Academic Publishers: Dordrecht, The Netherlands, 2015; pp. 233-236.

27. Fujino, Y.; Ohnishi, M. Structure of cerebroside in Aspergillus oryzae. Biochim. Biophys. Acta 1976, 486, 161-171.

28. Takakuwa, N.; Tanji, M.; Oda, Y.; Ohnishi, M. Distribution of 9-methyl sphingoid base in mushrooms and its effects on the fluidity of phospholipid liposomes. J. Oleo Sci. 2002, 51, 741-747. [CrossRef]

29. Sugawara, T.; Zaima, N.; Yamamoto, A.; Sakai, S.; Noguchi, R.; Hirata, T. Isolation of sphingoid bases of sea cucumber cerebrosides and their cytotoxicity against human colon cancer cells. Biosci. Biotechnol. Biochem. 2006, 70, 2906-2912. [CrossRef]

30. Shah, A.K.M.A.; Kinoshita, M.; Kurihara, H.; Ohnishi, M.; Takahashi, K. Glycosylceramides obtain from the starfish Asterias amurensis Lütken. J. Oleo Sci. 2008, 57, 477-484. [CrossRef] [PubMed]

31. Kimura, K.; Itonori, S.; Kajiwara, C.; Hada, N.; Takeda, T.; Sugita, M. Structural elucidation of the neutral glycosphingolipids, mono-, di-, tri-and tetraglycosylceramides from the marine crab Erimacrus isenbeckii. J. Oleo Sci. 2014, 63, 269-280. [CrossRef]

32. Tomonaga, N.; Manabe, Y.; Sugawara, T. Digestion of ceramide 2-aminoethylphosphonate, a sphingolipid from the jumbo flying squid Dosidicus gigas, in mice. Lipids 2017, 52, 353-362. [CrossRef] [PubMed]

33. Mikami, D.; Sakai, S.; Nishimukai, M.; Yuyama, K.; Mukai, K.; Igarashi, Y. Structure-dependent absorption of atypical sphingoid long-chain bases from digestive tract into lymph. Lipids Health Dis. 2021, 20, 24. [CrossRef] [PubMed]

34. Ramstedt, B.; Leppimäki, P.; Axberg, M.; Slotte, J.P. Analysis of natural and synthetic sphingomyelins using high-performance thin-layer chromatography. Eur. J. Biochem. 1999, 266, 997-1002. [CrossRef]

35. Yunoki, K.; Renaguli, M.; Kinoshita, M.; Matsuyama, H.; Mawatari, S.; Fujino, T.; Kodama, Y.; Sugiyama, M.; Ohnishi, M. Dietary sphingolipids ameliorate disorders of lipid metabolism in Zucker fatty rats. J. Agric. Food Chem. 2010, 58, 7030-7035. [CrossRef] [PubMed]

36. Takakuwa, N.; Saito, K.; Ohnishi, M.; Oda, Y. Determination of glucosylceramide contents in crop tissues and by-products from their processing. Bioresour. Technol. 2005, 96, 1089-1092. [CrossRef] [PubMed]

37. Yunoki, K.; Ogawa, T.; Ono, J.; Miyashita, R.; Aida, K.; Oda, Y.; Ohnishi, M. Analysis of sphingolipid classes and their contents in meals. Biosci. Biotechnol. Biochem. 2008, 72, 222-225. [CrossRef]

38. Sugawara, T.; Miyazawa, T. Separation and determination of glycolipids from edible plant sources by high-performance liquid chromatography and evaporative light-scattering detection. Lipids 1999, 34, 1231-1237. [CrossRef]

39. Nilsson, A. Metabolism of sphingomyelin in the intestinal tract of the rat. Biochim. Biophys. Acta 1968, 164, 575-584. [CrossRef]

40. Nilsson, A. Metabolism of cerebroside in the intestinal tract of the rat. Biochim. Biophys. Acta 1969, 176, 339-347. [CrossRef]

41. Hasi, R.Y.; Miyagi, M.; Kida, T.; Fukuta, T.; Kogure, K.; Hayashi, J.; Kawakami, R.; Kanemaru, K.; Tanaka, T. Quantitative analysis of glycosylinositol phosphoceramide and phytoceramide 1-phosphate in vegetables. J. Nutr. Sci. Vitaminol. 2019, 65, S175-S179. [CrossRef]

42. Tomonaga, N.; Tsuduki, T.; Manabe, Y.; Sugawara, T. Sphingoid bases of dietary ceramide 2-aminoethylphosphonate, a marine sphingolipid, absorb into lymph in rats. J. Lipid Res. 2019, 60, 333-340. [CrossRef]

43. Ohta, K.; Hiraki, S.; Miyanabe, M.; Ueki, T.; Aida, K.; Manabe, Y.; Sugawara, T. Appearance of intact molecules of dietary ceramides prepared from soy sauce lees and rice glucosylceramides in mouse plasma. J. Agric. Food Chem. 2021. Preprint. [CrossRef]

44. Dickson, J.J.; Messer, M. Intestinal neuraminidase activity of suckling rats and other mammals. Relationship to the sialic acid content of milk. Biochem. J. 1978, 170, 407-413. [CrossRef] [PubMed]

45. Nilsson, A. Role of sphingolipids in infant gut health and immunity. J. Pediatr. 2016, 173, S53-S59. [CrossRef] [PubMed]

46. Schmelz, E.M.; Sullards, M.C.; Dillehay, D.L.; Merrill, A.H., Jr. Colonic cell proliferation and aberrant crypt foci formation are inhibited by dairy glycosphingolipids in 1, 2-dimethylhydrazine-treated CF1 mice. J. Nutr. 2000, 130, 522-527. [CrossRef]

47. Leese, H.J.; Semenza, G. On the identity between the small intestinal enzymes phlorizin hydrolase and glycosylceramidase. J. Biol. Chem. 1973, 248, 8170-8173. [CrossRef]

48. Sugawara, T.; Kinoshita, M.; Ohnishi, M.; Nagata, J.; Saito, M. Digestion of maize sphingolipids in rats and uptake of sphingadienine by Caco-2 cells. J. Nutr. 2003, 133, 2777-2782. [CrossRef]

49. Sugawara, T.; Kinoshita, M.; Ohnishi, M.; Tsuzuki, T.; Miyazawa, T.; Nagata, J.; Hirata, T.; Saito, M. Efflux of sphingoid bases by P-glycoprotein in human intestinal Caco-2 cells. Biosci. Biotechnol. Biochem. 2004, 68, 2541-2546. [CrossRef]

50. Fujii, A.; Manabe, Y.; Aida, K.; Tsuduki, T.; Hirata, T.; Sugawara, T. Selective absorption of dietary sphingoid bases from the intestine via efflux by p-glycoprotein in rats. J. Nutr. Sci. Vitaminol. 2017, 63, 44-50. [CrossRef]

51. García-Barros, M.; Coant, N.; Truman, J.P.; Snider, A.J.; Hannun, Y.A. Sphingolipids in colon cancer. Biochim. Biophys. Acta 2014, 1841, 773-782. [CrossRef]

52. Zhang, P.; Li, B.; Gao, S.; Duan, R.D. Dietary sphingomyelin inhibits colonic tumorigenesis with an up-regulation of alkaline sphingomyelinase expression in ICR mice. Anticancer Res. 2008, 28, 3631-3635.

53. Schmelz, E.M.; Dillehay, D.L.; Webb, S.K.; Reiter, A.; Adams, J.; Merrill, A.H., Jr. Sphingomyelin consumption suppresses aberrant colonic crypt foci and increases the proportion of adenomas versus adenocarcinomas in CF1 mice treated with 1,2dimethylhydrazine: Implications for dietary sphingolipids and colon carcinogenesis. Cancer Res. 1996, 56, $4936-4941$. 
54. Schmelz, E.M.; Bushnev, A.S.; Dillehay, D.L.; Liotta, D.C.; Merrill, A.H., Jr. Suppression of aberrant colonic crypt foci by synthetic sphingomyelins with saturated or unsaturated sphingoid base backbones. Nutr. Cancer 1997, 28, 81-85. [CrossRef]

55. Lemonnier, L.A.; Dillehay, D.L.; Vespremi, M.J.; Abrams, J.; Brody, E.; Schmelz, E.M. Sphingomyelin in the suppression of colon tumors: Prevention versus intervention. Arch. Biochem. Biophys. 2003, 419, 129-138. [CrossRef]

56. Exon, J.H.; South, E.H. Effects of sphingomyelin on aberrant colonic crypt foci development, colon crypt cell proliferation and immune function in an aging rat tumor model. Food Chem. Toxicol. 2003, 41, 471-476. [CrossRef]

57. Hu, Y.; Le Leu, R.K.; Belobrajdic, D.; Young, G.P. The potential of sphingomyelin as a chemopreventive agent in AOM-induced colon cancer model: Wild-type and $p 53^{+/-}$mice. Mol. Nutr. Food Res. 2008, 52, 558-566. [CrossRef]

58. Aida, K.; Kinoshita, M.; Tanji, M.; Sugawara, T.; Tamura, M.; Ono, J.; Ueno, N.; Ohnishi, M. Prevention of aberrant crypt foci formation by dietary maize and yeast cerebrosides in 1,2-dimethylhydrazine-treated mice. J. Oleo Sci. 2005, 54, 45-49. [CrossRef]

59. Kinoshita, M.; Aida, K.; Tokuji, Y.; Sugawara, T.; Ohnishi, M. Effects of dietary plant cerebroside on gene expression in the large intestine of 1,2-dimethylhydrazine (DMH)-treated mice determined by DNA microarray analysis. J. Food Lipids 2009, 16, 200-208. [CrossRef]

60. Yamashita, S.; Sakurai, R.; Hishiki, K.; Aida, K.; Kinoshita, M. Effects of dietary plant-origin glucosylceramide on colon cytokine contents in DMH-treated mice. J. Oleo Sci. 2017, 66, 157-160. [CrossRef]

61. Inamine, M.; Suzui, M.; Morioka, T.; Kinjo, T.; Kaneshiro, T.; Sugishita, T.; Okada, T.; Yoshimi, N. Inhibitory effect of dietary monoglucosylceramide 1-O-beta-glucosyl- $\mathrm{N}-2^{\prime}$-hydroxyarachidoyl-4,8-sphingadienine on two different categories of colon preneoplastic lesions induced by 1,2-dimethylhydrazine in F344 rats. Cancer Sci. 2005, 96, 876-881. [CrossRef]

62. Symolon, H.; Schmelz, E.M.; Dillehay, D.L.; Merrill, A.H., Jr. Dietary soy sphingolipids suppress tumorigenesis and gene expression in 1,2-dimethylhydrazine-treated CF1 mice and $A p c^{M i n /+}$ mice. J. Nutr. 2004, 134, 1157-1161. [CrossRef]

63. Schmelz, E.M.; Roberts, P.C.; Kustin, E.M.; Lemonnier, L.A.; Sullards, M.C.; Dillehay, D.L.; Merrill, A.H., Jr. Modulation of intracellular $\beta$-catenin localization and intestinal tumorigenesis in vivo and in vitro by sphingolipids. Cancer Res. 2001, 61, 6723-6729.

64. Symolon, H.; Bushnev, A.; Peng, Q.; Ramaraju, H.; Mays, S.G.; Allegood, J.C.; Pruett, S.T.; Sullards, M.C.; Dillehay, D.L.; Liotta, D.C.; et al. Enigmol: A novel sphingolipid analogue with anticancer activity against cancer cell lines and in vivo models for intestinal and prostate cancer. Mol. Cancer Ther. 2011, 10, 648-657. [CrossRef] [PubMed]

65. Kariyawasam, K.M.G.R.M.; Yamashita, S.; Fukuda, K.; Ohwada, T.; Kinoshita, M. Preventing the formation of aberrant crypt foci in 1,2-dimethylhydrazine-treated mice by dietary milk and maitake mushroom (Grifola frondosa). Milk Sci. 2019, 68, 85-93.

66. Kariyawasam, K.M.G.R.M.; Yamashita, S.; Fukuma, N.; Kinoshita, M. Dietary milk and maitake mushroom (Grifola frondosa) modulate inflammation-related cytokines and apoptosis related-proteins in colon of 1,2-dimethylhydrazine-treated mice. Milk Sci. 2020, 69, 21-28.

67. Arai, K.; Yamazaki, T.; Tokuji, Y.; Kawahara, M.; Ohba, K.; Hironaka, K.; Kinoshita, M.; Ohnishi, M. Effects of Chinese yam storage protein on formation of aberrant crypt foci in 1,2-dimethylhydrazine-treated mice. J. Food Nutr. Res. 2013, 52, $139-145$.

68. Yamashita, S.; Yamamoto, M.; Hirakawa, K.; Kikuchi, N.; Kinoshita, M.; Miyazawa, T. Extraction of lipophilic fraction from polished rice improves its ameliorative effect on intestinal impairment. J. Oleo Sci. 2019, 68, 463-470. [CrossRef]

69. Yamashita, S.; Hata, M.; Kikuchi, N.; Kinoshita, M.; Miyazawa, T. Effects of dietary ethanol extracts from sake rice and sake lees on intestinal impairment in mice. J. Oleo Sci. 2020, 69, 929-939. [CrossRef]

70. Schmelz, E.M.; Bushnev, A.S.; Dillehay, D.L.; Sullards, M.C.; Liotta, D.C.; Merrill, A.H., Jr. Ceramide- $\beta$-D-glucuronide: Synthesis, digestion, and suppression of early markers of colon carcinogenesis. Cancer Res. 1999, 59, 5768-5772.

71. Ahn, E.H.; Schroeder, J.J. Sphingoid bases and ceramide induce apoptosis in HT-29 and HCT-116 human colon cancer cells. Exp. Biol. Med. 2002, 227, 345-353. [CrossRef] [PubMed]

72. Ahn, E.H.; Schroeder, J.J. Induction of apoptosis by sphingosine, sphinganine, and $\mathrm{C}_{2}$-ceramide in human colon cancer cells, but not by $\mathrm{C}_{2}$-dihydroceramide. Anticancer Res. 2010, 30, 2881-2884.

73. Sugawara, T.; Kinoshita, M.; Ohnishi, M.; Miyazawa, T. Apoptosis induction by wheat-flour sphingoid bases in DLD-1 human colon cancer cells. Biosci. Biotechnol. Biochem. 2002, 66, 2228-2231. [CrossRef] [PubMed]

74. Aida, K.; Kinoshita, M.; Sugawara, T.; Ono, J.; Miyazawa, T.; Ohnishi, M. Apoptosis inducement by plant and fungus sphingoid bases in human colon cancer cells. J. Oleo Sci. 2004, 53, 503-510. [CrossRef]

75. Morad, S.A.; Madigan, J.P.; Levin, J.C.; Abdelmageed, N.; Karimi, R.; Rosenberg, D.W.; Kester, M.; Shanmugavelandy, S.S.; Cabot, M.C. Tamoxifen magnifies therapeutic impact of ceramide in human colorectal cancer cells independent of $p 53$. Biochem. Pharmacol. 2013, 85, 1057-1065. [CrossRef]

76. Rahmaniyan, M.; Curley, R.W., Jr.; Obeid, L.M.; Hannun, Y.A.; Kraveka, J.M. Identification of dihydroceramide desaturase as a direct in vitro target for fenretinide. J. Biol. Chem. 2011, 286, 24754-24764. [CrossRef]

77. Snider, A.J.; Kawamori, T.; Bradshaw, S.G.; Orr, K.A.; Gilkeson, G.S.; Hannun, Y.A.; Obeid, L.M. A role for sphingosine kinase 1 in dextran sulfate sodium-induced colitis. FASEB J. 2009, 23, 143-152. [CrossRef]

78. Pulkoski-Gross, M.J.; Uys, J.D.; Orr-Gandy, K.A.; Coant, N.; Bialkowska, A.B.; Szulc, Z.M.; Bai, A.; Bielawska, A.; Townsend, D.M.; Hannun, Y.A.; et al. Novel sphingosine kinase-1 inhibitor, LCL351, reduces immune responses in murine DSS induced colitis. Prostaglandins Other Lipid Mediat. 2017, 130, 47-56. [CrossRef]

79. Okazaki, T.; Bell, R.M.; Hannun, Y.A. Sphingomyelin turnover induced by vitamin D3 in HL-60 cells. Role in cell differentiation. J. Biol. Chem. 1989, 264, 19076-19080. [CrossRef] 
80. Ohnishi, T.; Hashizume, C.; Taniguchi, M.; Furumoto, H.; Han, J.; Gao, R.; Kinami, S.; Kosaka, T.; Okazaki, T. Sphingomyelin synthase 2 deficiency inhibits the induction of murine colitis-associated colon cancer. FASEB J. 2017, 31, 3816-3830. [CrossRef] [PubMed]

81. Scheffel, M.J.; Helke, K.; Lu, P.; Bowers, J.S.; Ogretmen, B.; Garrett-Mayer, E.; Paulos, C.M.; Voelkel-Johnson, C. Adoptive transfer of ceramide synthase 6 deficient splenocytes reduces the development of colitis. Sci. Rep. 2017, 7, 15552. [CrossRef] [PubMed]

82. Furuya, H.; Ohkawara, S.; Nagashima, K.; Asanuma, N.; Hino, T. Dietary sphingomyelin alleviates experimental inflammatory bowel disease in mice. Int. J. Vitam. Nutr. Res. 2008, 78, 41-49. [CrossRef] [PubMed]

83. Fischbeck, A.; Leucht, K.; Frey-Wagner, I.; Bentz, S.; Pesch, T.; Kellermeier, S.; Krebs, M.; Fried, M.; Rogler, G.; Hausmann, M.; et al. Sphingomyelin induces cathepsin D-mediated apoptosis in intestinal epithelial cells and increases inflammation in DSS colitis. Gut 2011, 60, 55-65. [CrossRef]

84. Mazzei, J.C.; Zhou, H.; Brayfield, B.P.; Hontecillas, R.; Bassaganya-Riera, J.; Schmelz, E.M. Suppression of intestinal inflammation and inflammation-driven colon cancer in mice by dietary sphingomyelin: Importance of peroxisome proliferator-activated receptor $\gamma$ expression. J. Nutr. Biochem. 2011, 22, 1160-1171. [CrossRef]

85. Sakata, A.; Ochiai, T.; Shimeno, H.; Hikishima, S.; Yokomatsu, T.; Shibuya, S.; Toda, A.; Eyanagi, R.; Soeda, S. Acid sphingomyelinase inhibition suppresses lipopolysaccharide-mediated release of inflammatory cytokines from macrophages and protects against disease pathology in dextran sulphate sodium-induced colitis in mice. Immunology 2007, 122, 54-64. [CrossRef]

86. Fekry, B.; Jeffries, K.A.; Esmaeilniakooshkghazi, A.; Szulc, Z.M.; Knagge, K.J.; Kirchner, D.R.; Horita, D.A.; Krupenko, S.A.; Krupenko, N.I. C16-ceramide is a natural regulatory ligand of $p 53$ in cellular stress response. Nat. Commun. 2018, 9, 4149. [CrossRef] [PubMed]

87. Dadsena, S.; Bockelmann, S.; Mina, J.G.M.; Hassan, D.G.; Korneev, S.; Razzera, G.; Jahn, H.; Niekamp, P.; Müller, D.; Schneider, M.; et al. Ceramides bind VDAC2 to trigger mitochondrial apoptosis. Nat. Commun. 2019, 10, 1832. [CrossRef] [PubMed]

88. Arai, K.; Mizobuchi, Y.; Tokuji, Y.; Aida, K.; Yamashita, S.; Ohnishi, M.; Kinoshita, M. Effects of dietary plant-origin glucosylceramide on bowel inflammation in DSS-treated mice. J. Oleo Sci. 2015, 64, 737-742. [CrossRef]

89. Park, E.J.; Suh, M.; Thomson, B.; Ma, D.W.; Ramanujam, K.; Thomson, A.B.; Clandinin, M.T. Dietary ganglioside inhibits acute inflammatory signals in intestinal mucosa and blood induced by systemic inflammation of Escherichia coli lipopolysaccharide. Shock 2007, 28, 112-117. [CrossRef]

90. Park, E.J.; Thomson, A.B.; Clandinin, M.T. Protection of intestinal occludin tight junction protein by dietary gangliosides in lipopolysaccharide-induced acute inflammation. J. Pediatr. Gastroenterol. Nutr. 2010, 50, 321-328. [CrossRef]

91. Norris, G.H.; Blesso, C.N. Dietary and endogenous sphingolipid metabolism in chronic inflammation. Nutrients 2017, 9, 1180. [CrossRef]

92. Yamashita, S.; Akada, K.; Matsumoto, S.; Kinoshita, M. Effects of dietary ethanol extract from fruiting bodies of golden oyster mushroom (Pleurotus citrinopileatus) on chronic colon inflammation in mice treated with dextran sulfate sodium salt. Mushroom Sci. Biotechnol. 2020, 28, 7-14.

93. Yamashita, S.; Seino, T.; Inobe, M.; Jutanom, M.; Matsumoto, S.; Kinoshita, M. Polar lipid fraction from golden oyster mushrooms (Pleurotus citrinopileatus) suppresses colon injuries from inflammatory stresses in vivo and in vitro. J. Oleo Sci. 2020, 69, 751-757. [CrossRef]

94. Schnabl, K.L.; Larsen, B.; van Aerde, J.E.; Lees, G.; Evans, M.; Belosevic, M.; Field, C.; Thomson, A.B.; Clandinin, M.T. Gangliosides protect bowel in an infant model of necrotizing enterocolitis by suppressing proinflammatory signals. J. Pediatr. Gastroenterol. Nutr. 2009, 49, 382-392. [CrossRef]

95. Yamashita, S.; Seino, T.; Aida, K.; Kinoshita, M. Effects of plant sphingolipids on inflammatory stress in differentiated Caco-2 cells. J. Oleo Sci. 2017, 66, 1337-1342. [CrossRef]

96. Jutanom, M.; Higaki, C.; Yamashita, S.; Nakagawa, K.; Matsumoto, S.; Kinoshita, M. Effects of sphingolipid fractions from golden oyster mushroom (Pleurotus citrinopileatus) on apoptosis induced by inflammatory stress in an intestinal tract in vitro model. $J$. Oleo Sci. 2020, 69, 1087-1093. [CrossRef] [PubMed]

97. Noriris, G.H.; Porter, C.M.; Jiang, J.; Blesso, C.N. Dietary milk sphingomyelin reduces systemic inflammation in diet-induced obese mice and inhibits LPS activity in macrophages. Beverages 2017, 3, 37. [CrossRef]

98. Sakamoto, H.; Yoshida, T.; Sanaki, T.; Shigaki, S.; Morita, H.; Oyama, M.; Mitsui, M.; Tanaka, Y.; Nakano, T.; Mitsutake, S.; et al. Possible roles of long-chain sphingomyelines and sphingomyelin synthase 2 in mouse macrophage inflammatory response. Biochem. Biophys. Res. Commun. 2017, 482, 202-207. [CrossRef] [PubMed]

99. Noh, S.K.; Koo, S.I. Milk sphingomyelin is more effective than egg sphingomyelin in inhibiting intestinal absorption of cholesterol and fat in rats. J. Nutr. 2004, 134, 2611-2616. [CrossRef] [PubMed]

100. Noriris, G.H.; Jiang, J.; Ryan, J.; Porter, C.M.; Blesso, C.N. Milk sphingomyelin improves lipid metabolism and alters gut microbiota in high fat diet-fed mice. J. Nutr. Biochem. 2016, 30, 93-101. [CrossRef]

101. Chen, H.; Born, E.; Mathur, S.N.; Johlin, F.C., Jr.; Field, F.J. Sphingomyelin content of intestinal cell membranes regulates cholesterol absorption. Evidence for pancreatic and intestinal cell sphingomyelinase activity. Biochem. J. 1992, 286, 771-777. [CrossRef]

102. Kirby, R.J.; Zheng, S.; Tso, P.; Howles, P.N.; Hui, D.Y. Bile salt-stimulated carboxyl ester lipase influences lipoprotein assembly and secretion in intestine: A process mediated via ceramide hydrolysis. J. Biol. Chem. 2001, 277, 4104-4109. [CrossRef] 
103. Garmy, N.; Taieb, N.; Yahi, N.; Fantini, J. Interaction of cholesterol with sphingosine: Physicochemical characterization and impact on intestinal absorption. J. Lipid Res. 2005, 46, 36-45. [CrossRef] [PubMed]

104. Yang, J.Y.; Zhang, T.T.; Dong, Z.; Shi, H.H.; Xu, J.; Mao, X.Z.; Wang, Y.M.; Xue, C.H. Dietary supplementation with exogenous seacucumber-derived ceramides and glucosylceramides alleviates insulin resistance in high-fructose-diet-fed rats by upregulating the IRS/PI3K/Akt signaling pathway. J. Agric. Food Chem. 2021. Preprint. [CrossRef]

105. Simon, K.W.; Tait, L.; Miller, F.; Cao, C.; Davy, K.P.; LeRoith, T.; Schmelz, E.M. Suppression of breast xenograft growth and progression in nude mice: Implications for the use of orally administered sphingolipids as chemopreventive agents against breast cancer. Food Funct. 2010, 1, 90-98. [CrossRef]

106. Fujiwara, K.; Yazama, H.; Donishi, R.; Koyama, S.; Fukuhara, T.; Takeuchi, H. Inhibitory effects of glucosylceramide on tumorigenesis induced by a carcinogen in mice. Laryngoscope 2020, 130, E593-E597. [CrossRef]

107. Hamajima, H.; Matsunaga, H.; Fujikawa, A.; Sato, T.; Mitsutake, S.; Yanagita, T.; Nagao, K.; Nakayama, J.; Kitagaki, H. Japanese traditional dietary fungus koji Aspergillus oryzae functions as a prebiotic for Blautia coccoides through glycosylceramide: Japanese dietary fungus koji is a new prebiotic. Springerplus 2016, 5, 1321. [CrossRef] [PubMed]

108. Lee, M.T.; Le, H.H.; Johnson, E.L. Dietary sphinganine is selectively assimilated by members of the mammalian gut microbiome. J. Lipid Res. 2021, 62, 100034. [CrossRef]

109. Ono, J.; Kinoshita, M.; Aida, K.; Tamura, M.; Ohnishi, M. Effects of dietary glucosylceramide on dermatitis in atopic dermatitis model mice. Eur. J. Lipid Sci. Technol. 2010, 112, 708-711. [CrossRef]

110. Uchiyama, T.; Nakano, Y.; Ueda, O.; Mori, H.; Nakashima, M.; Noda, A.; Ishizaki, C.; Mizoguchi, M. Oral intake of glucosylceramide improves relatively higher level of transepidermal water loss in mice and healthy human subjects. J. Health Sci. 2008, 54, 559-566. [CrossRef]

111. Duan, J.; Sugawara, T.; Hirose, M.; Aida, K.; Sakai, S.; Fujii, A.; Hirata, T. Dietary sphingolipids improve skin barrier functions via the upregulation of ceramide synthases in the epidermis. Exp. Dermatol. 2012, 21, 448-452. [CrossRef] [PubMed]

112. Hirakawa, S.; Sato, A.; Hattori, Y.; Matsumoto, T.; Yokoyama, K.; Kanai, A. Dietary rice bran extract improves TEWL of whole body. Jpn. Pharmacol. Ther. 2013,41, 1051-1059.

113. Oba, C.; Morifuji, M.; Ichikawa, S.; Ito, K.; Kawahata, K.; Yamaji, T.; Asami, Y.; Itou, H.; Sugawara, T. Dietary milk sphingomyelin prevents disruption of skin barrier function in hairless mice after UV-B irradiation. PLoS ONE 2015, 10, e0136377. [CrossRef]

114. Tsuchiya, Y.; Ban, M.; Kishi, M.; Ono, T.; Masaki, H. Safety and efficacy of oral intake of ceramide-containing acetic acid bacteria for improving the stratum corneum hydration: A randomized, double-blind, placebo-controlled study over 12 weeks. J. Oleo Sci. 2020, 69, 1497-1508. [CrossRef]

115. Ueda, O.; Hasegawa, M.; Kitamura, S. Distribution in skin of ceramide after oral administration to rats. Drug Metab. Pharmacokinet. 2009, 24, 180-184. [CrossRef] [PubMed]

116. Ueda, O.; Uchiyama, T.; Nakashima, M. Distribution and metabolism of sphingosine in skin after oral administration to mice. Drug Metab. Pharmacokinet. 2010, 25, 456-465. [CrossRef] [PubMed]

117. Shirakura, Y.; Kikuchi, K.; Matsumura, K.; Mukai, K.; Mitsutake, S.; Igarashi, Y. 4,8-Sphingadienine and 4-hydroxy-8-sphingenine activate ceramide production in the skin. Lipids Health Dis. 2012, 11, 108. [CrossRef]

118. Rohrhofer, J.; Zwirzitz, B.; Selberherr, E.; Untersmayr, E. The impact of dietary sphingolipids on intestinal microbiota and gastrointestinal immune homeostasis. Front. Immunol. 2021, 12, 5704. [CrossRef] 